\title{
Synthesis and Characterization of Andrographolide Derivatives as Regulators of $\beta$ APP Processing in Human Cells
}

\author{
Arpita Dey ${ }^{1,+}+\mathbb{C}$, Ran Chen ${ }^{2,+}{ }^{,}$Feng Li ${ }^{2}$, Subhamita Maitra ${ }^{1}$, Jean-Francois Hernandez ${ }^{3}$, Guo-Chun Zhou ${ }^{2, *(1)}$ \\ and Bruno Vincent $1,4, *$ \\ 1 Institute of Molecular Biosciences, Mahidol University, Nakhon Pathom 73170, Thailand; \\ atipra.4evr@gmail.com (A.D.); msubhamita4u@yahoo.com (S.M.) \\ 2 School of Pharmaceutical Sciences, Nanjing Tech University, Nanjing 211816, China; \\ 202162118026@njtech.edu.cn (R.C.); fengli9203@163.com (F.L.) \\ 3 Institut des Biomolécules Max Mousseron, UMR5247 CNRS/Université de Montpellier/ENSCM, \\ Faculté de Pharmacie, CEDEX 5, 34093 Montpellier, France; jean-francois.hernandez@umontpellier.fr \\ 4 Centre National de la Recherche Scientifique, 2 rue Michel Ange, 75016 Paris, France \\ * Correspondence: gczhou@njtech.edu.cn (G.-C.Z.); bruno.vin@mahidol.ac.th (B.V.); Tel.: +66-809-71-2696 (B.V.) \\ + These authors contributed equally to this work.
}

check for updates

Citation: Dey, A.; Chen, R.; Li, F.; Maitra, S.; Hernandez, J.-F.; Zhou, G.-C.; Vincent, B. Synthesis and Characterization of Andrographolide Derivatives as Regulators of $\beta$ APP Processing in Human Cells. Molecules 2021, 26, 7660. https://doi.org/ $10.3390 /$ molecules 26247660

Academic Editor:

Aleksandra Misicka-Kesik

Received: 18 November 2021 Accepted: 10 December 2021 Published: 17 December 2021

Publisher's Note: MDPI stays neutral with regard to jurisdictional claims in published maps and institutional affiliations.

Copyright: (c) 2021 by the authors. Licensee MDPI, Basel, Switzerland. This article is an open access article distributed under the terms and conditions of the Creative Commons Attribution (CC BY) license (https:// creativecommons.org/licenses/by/ $4.0 /)$.

\begin{abstract}
Alzheimer's disease (AD) is a devastating neurodegenerative disorder, one of the main characteristics of which is the abnormal accumulation of amyloid peptide $(\mathrm{A} \beta)$ in the brain. Whereas $\beta$-secretase supports $A \beta$ formation along the amyloidogenic processing of the $\beta$-amyloid precursor protein $(\beta \mathrm{APP}), \alpha$-secretase counterbalances this pathway by both preventing $\mathrm{A} \beta$ production and triggering the release of the neuroprotective $\operatorname{sAPP} \alpha$ metabolite. Therefore, stimulating $\alpha$-secretase and/or inhibiting $\beta$-secretase can be considered a promising anti-AD therapeutic track. In this context, we tested andrographolide, a labdane diterpene derived from the plant Andrographis paniculata, as well as 24 synthesized derivatives, for their ability to induce sAPP $\alpha$ production in cultured SH-SY5Y human neuroblastoma cells. Following several rounds of screening, we identified three hits that were subjected to full characterization. Interestingly, andrographolide (8,17-olefinic) and its close derivative $14 \alpha$ - $\left(5^{\prime}, 7^{\prime}\right.$-dichloro- $8^{\prime}$-quinolyloxy)-3,19-acetonylidene (compound 9) behave as moderate $\alpha$-secretase activators, while $14 \alpha-\left(2^{\prime}\right.$-methyl- $5^{\prime}, 7^{\prime}$-dichloro- $8^{\prime}$-quinolyloxy)-8,9-olefinic compounds 31 (3,19-acetonylidene) and 37 (3,19-diol), whose two structures are quite similar although distant from that of andrographolide and $\mathbf{9}$, stand as $\beta$-secretase inhibitors. Importantly, these results were confirmed in human HEK293 cells and these compounds do not trigger toxicity in either cell line. Altogether, these findings may represent an encouraging starting point for the future development of andrographolide-based compounds aimed at both activating $\alpha$-secretase and inhibiting $\beta$-secretase that could prove useful in our quest for the therapeutic treatment of AD.
\end{abstract}

Keywords: Alzheimer's disease; $\beta$ APP; andrographolide; $\alpha$-secretase; $\beta$-secretase; neuroprotection

\section{Introduction}

Alzheimer's disease (AD) is the most prevalent neurodegenerative disorder and the main cause of dementia worldwide. It is characterized by a progressive loss of memory and cognitive function, which ultimately lead to dementia and death. Pathologically, there is an accumulation of extracellular $\beta$-amyloid peptide $(\mathrm{A} \beta)$ in senile plaques and of intracellular hyper-phosphorylated tau-containing neurofibrillary tangles (NTFs) in the hippocampus and cerebral cortex. This is accompanied by a large panel of molecular events related to the progression of the disease including oxidative stress, neuroinflammation, mitochondrial dysfunction, altered calcium homeostasis, and apoptosis [1].

The $A \beta$ peptides are produced from the $\beta$-amyloid precursor protein $(\beta A P P)$ along the amyloidogenic pathway through the sequential cleavages by $\beta$-secretase (BACE1) and the heterotetrameric $\gamma$-secretase complex that also gives rise to the production of the $\mathrm{APP} \beta$, 
C99, and AICD metabolites [2]. At the same time, a major alternative non-amyloidogenic route involves $\alpha$-secretase activity. It not only hampers the production of the amyloid peptide since cleavage occurs in the middle of the $A \beta$ sequence, but it also leads to the secretion of the metabolite sAPP $\alpha$ with neuroprotective and neurotrophic powers [3]. Therefore, $\alpha$-secretase activation appears as a promising therapeutic strategy aimed at preventing $\mathrm{AD}[4,5]$. Unfortunately, sustained efforts to inhibit and/or modulate $\beta$ - and $\gamma$-secretases or to activate $\alpha$-secretases are still unsuccessful, this being mainly explained by the fact that these enzymes cleave numerous other substrates involved in vital physiological functions [6-8]. Hence, the use of plant-derived active compounds has increasingly been considered in recent years as an alternative to pharmacotherapies [9] because side-effects for most medicinally used natural products are considerably low or inexistent.

Andrographolide (Scheme 1) is a bicyclic diterpenoid lactone present in the stem and leaves of Andrographis paniculata. As the major bioactive constituent of this traditional Asian medicinal herb, it supports its antioxidant, anti-microbial, anti-inflammatory, and anti-cancer properties [10]. Interestingly, several beneficial effects of andrographolide on physiological functions of the central nervous system have been reported in recent years as shown by the ability of the compound to stimulate adult neurogenesis in the mouse hippocampus [11] and the capacity of andrographolide analogues to promote neurite outgrowth in rat PC-12 cells [12]. Furthermore, several studies have very recently evidenced some positive effects of andrographolide on AD pathology. Firstly, it can strongly attenuate $\mathrm{A} \beta$-induced microglial activation $[13,14]$ and autophagy-associated cell death [15] in vitro. Secondly and most importantly, andrographolide administration has been shown to alleviate AD-associated phenotypes, including cognitive deficits, observed in both transgenic [16-18] and non-transgenic $[19,20]$ models of the disease.

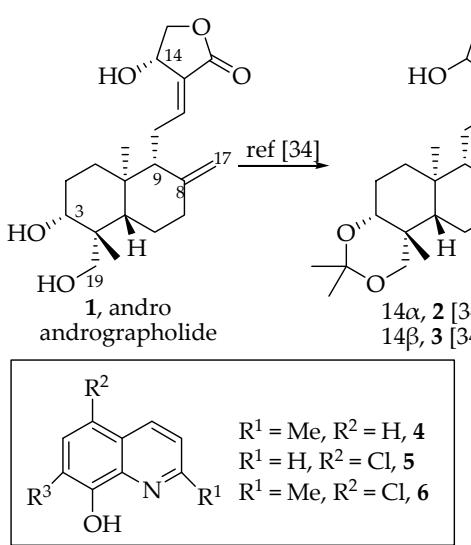

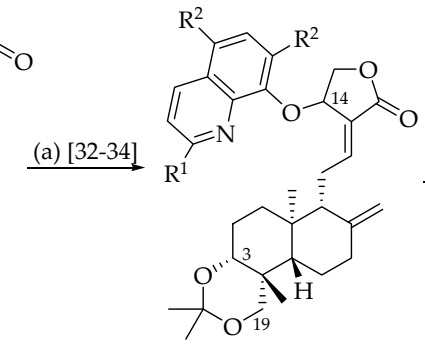

$14 \alpha, \mathrm{R}^{1}=\mathrm{Me}, \mathrm{R}^{2}=\mathrm{H}, 7$ [32] from 3 and 4 $14 \beta, \mathrm{R}^{1}=\mathrm{Me}, \mathrm{R}^{2}=\mathrm{H}, 8$ [32] from 2 and 4 $14 \alpha, \mathrm{R}^{1}=\mathrm{H}, \mathrm{R}^{2}=\mathrm{Cl}, \mathbf{9}$ [32] from 3 and 5 $14 \beta, \mathrm{R}^{1}=\mathrm{H}, \mathrm{R}^{2}=\mathrm{Cl}, 10$ [32] from 2 and 5 $14 \alpha, \mathrm{R}^{1}=\mathrm{Me}, \mathrm{R}^{2}=\mathrm{Cl}, 11$ from 3 and 6 $14 \beta, \mathrm{R}^{1}=\mathrm{Me}, \mathrm{R}^{2}=\mathrm{Cl}, 12$ [33] from 2 and 6

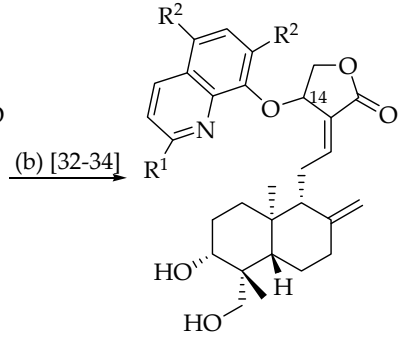

$14 \alpha, \mathrm{R}^{1}=\mathrm{Me}, \mathrm{R}^{2}=\mathrm{H}, 13$ [33] from 7 $14 \beta, \mathrm{R}^{1}=\mathrm{Me}, \mathrm{R}^{2}=\mathrm{H}, 14$ [33] from 8 $14 \alpha, \mathrm{R}^{1}=\mathrm{H}, \mathrm{R}^{2}=\mathrm{Cl}, \mathbf{1 5}[33]$ from 9 $14 \beta, \mathrm{R}^{1}=\mathrm{H}, \mathrm{R}^{2}=\mathrm{Cl}, 16$ [33] from 10 $14 \alpha, \mathrm{R}^{1}=\mathrm{Me}, \mathrm{R}^{2}=\mathrm{Cl}, 17$ from 11 $14 \beta, \mathrm{R}^{1}=\mathrm{Me}, \mathrm{R}^{2}=\mathrm{Cl}, 18$ from 12

Scheme 1. Reagents and conditions: (a) $\mathrm{Ph}_{3} \mathrm{P}$, DIAD with 4, 5, or 6 by Mitsunobu reaction; (b) $\mathrm{MeOH} / \mathrm{H}_{2} \mathrm{O}(4 / 1), \mathrm{TsOH} \cdot \mathrm{H}_{2} \mathrm{O}, 20^{\circ} \mathrm{C}$.

Mechanistically, it has been shown that andrographolide activates the canonical Wnt signaling pathway via an inhibition of GSK-3 $\beta$ in primary neurons [21] and in the aged rodent Octodon degus [22], and that it increases glucose uptake and utilization in a Wntdependent manner in the J20 transgenic mouse model of AD [23]. Interestingly, there exists a close relationship between Wnt loss of function and AD-associated neurodegeneration [24] mostly because of the ability of Wnt to repress the transcription of the $\beta$-secretase BACE1 [25]. Indeed, it has been established that andrographolide can shift the metabolism of $\beta$ APP towards the non-amyloidogenic pathway as shown by an increased production of $C 83$ and a concomitant decrease in $C 99$ and $A \beta 42 / A \beta 40$ ratio in epithelial cells overexpressing $\beta$ APP [26].

Because its simplistic structural nature brings amenability for semi-synthetic modifications, andrographolide has given rise to many derivatives with potent therapeutic effects in diverse fields [27]. In this context, we have undertaken to design, synthesize, and test twenty-four andrographolide derivatives, classified as two series, for their ability to 
favorably modulate $\beta$ APP processing through the stimulation of $\alpha$-secretase and / or the inhibition of $\beta$-secretase catalytic activities/expression in human neuroblastoma SH-SY5Y cells. A first screening allowed us to identify andrographolide as well as the three derivatives $9, \mathbf{3 1}$, and 37 as potent $\mathrm{SAPP} \alpha$ production-enhancing compounds without altering cell viability. Their subsequent full characterization indicated that while andrographolide and 9 could moderately stimulate the $\alpha$-secretase catalytic activity, $\mathbf{3 1}$ and $\mathbf{3 7}$ behaved as potent $\beta$-secretase inhibitors. These results thus established andrographolide and some of its derivatives as a promising basis for the future development of anti-amyloidogenic factors, the next generation of which hopefully leading to the setup of druggable $\alpha$-secretase activator $/ \beta$-secretase inhibitor compounds.

\section{Results}

\subsection{Synthesis of Andrographolide Derivatives}

Since andrographolide can exert neuroprotective effects $[26,28,29]$ and because the quinoline moiety is important in anti-AD compounds, thanks to its antioxidant, antiaggregating, and neurotrophic properties [28,30,31], we were interested in assessing the anti-AD activity of 24 andrographolide derivatives bearing a 14-quinolinyloxy group, and divided in 12 derivatives [32,33] of a 8,17-olefinic series (Scheme 1 ) and 12 derivatives of a 9-dehydro-17-hydro series (Scheme 2).

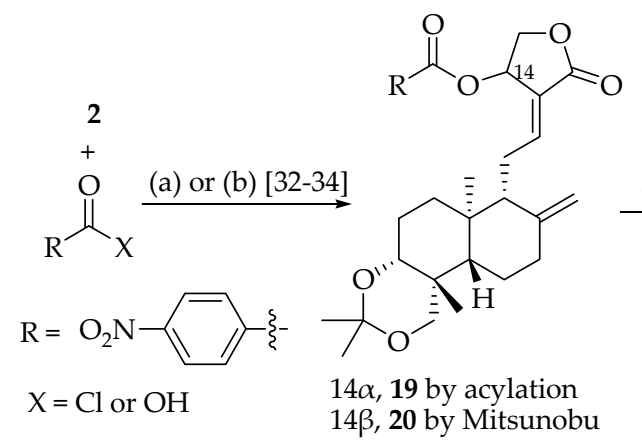

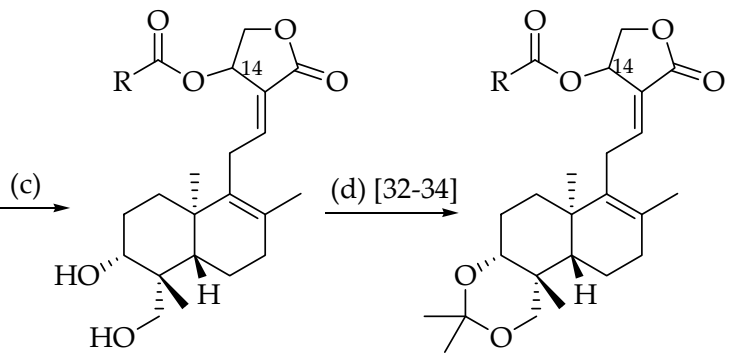
$14 \beta, 20$ by Mitsunobu

$14 \alpha, 21$ from 19 $14 \beta, 22$ from 20
$14 \alpha, 23$ from 21 $14 \beta, 24$ from 22<smiles>CC1=C(CC=C2C(=O)OCC2O)[C@]2(C)CC[C@H]3OC(C)(C)OC[C@H]3[C@H]2CC1</smiles>

$14 \alpha, 25$ from 23 $14 \beta, 26$ from 24

\section{(f) [32-34]}<smiles>[R]c1ccc2c([R])cc([R])c(OC3COC(=O)C3=CCC3=C(C)CC[C@H]4[C@H]5COC(C)(C)O[C@H]5CC[C@]34C)c2n1</smiles>

$14 \alpha, \mathrm{R}^{1}=\mathrm{Me}, \mathrm{R}^{2}=\mathrm{H}, 27$ from 26 and 4 $14 \beta, R^{1}=\mathrm{Me}, \mathrm{R}^{2}=\mathrm{H}, 28$ from 25 and 4 $14 \alpha, \mathrm{R}^{1}=\mathrm{H}, \mathrm{R}^{2}=\mathrm{Cl}, 29$ from 26 and 5 $14 \beta, \mathrm{R}^{1}=\mathrm{H}, \mathrm{R}^{2}=\mathrm{Cl}, 30$ from 25 and 5 $14 \alpha, \mathrm{R}^{1}=\mathrm{Me}, \mathrm{R}^{2}=\mathrm{Cl}, 31$ from 26 and 6 $14 \beta, \mathrm{R}^{1}=\mathrm{Me}, \mathrm{R}^{2}=\mathrm{Cl}, 32$ from 25 and 6<smiles>[131IH]</smiles><smiles>[R]c1ccc2c([R])cc([R])c(OC3COC(=O)C3=CCC3=C(C)CC[C@H]4[C@H]3CC[C@@H](O)[C@H]4CO)c2n1</smiles>

$14 \alpha, \mathrm{R}^{1}=\mathrm{Me}, \mathrm{R}^{2}=\mathrm{H}, 33$ from 27 $14 \beta, \mathrm{R}^{1}=\mathrm{Me}, \mathrm{R}^{2}=\mathrm{H}, 34$ from 28 $14 \alpha, \mathrm{R}^{1}=\mathrm{H}, \mathrm{R}^{2}=\mathrm{Cl}, 35$ from 29 $14 \beta, \mathrm{R}^{1}=\mathrm{H}, \mathrm{R}^{2}=\mathrm{Cl}, 36$ from 30 $14 \alpha, \mathrm{R}^{1}=\mathrm{Me}, \mathrm{R}^{2}=\mathrm{Cl}, 37$ from 31 $14 \beta, R^{1}=\mathrm{Me}, \mathrm{R}^{2}=\mathrm{Cl}, 38$ from 32

Scheme 2. Reagents and conditions: (a) acylation $(X=\mathrm{Cl})$ by $\mathrm{Et}_{3} \mathrm{~N}$ and 4-nitrobenzoyl chloride in DCM; (b) Mitsunobu reaction $(\mathrm{X}=\mathrm{OH})$ by $\mathrm{Ph}_{3} \mathrm{P}$, DIAD and 4-nitrobenzoic acid in THF; (c) $85 \%$ $\mathrm{H}_{3} \mathrm{PO}_{4}$; (d) anhydrous DCM, 2,2-dimethoxypropane, PPTS, $40{ }^{\circ} \mathrm{C}$; (e) $\mathrm{Li}_{2} \mathrm{CO}_{3}, \mathrm{MeOH}$; (f) 25 or 26, $\mathrm{Ph}_{3} \mathrm{P}$, DIAD with 4, 5, or 6 by Mitsunobu reaction; (g) $\mathrm{MeOH} / \mathrm{H}_{2} \mathrm{O}(4 / 1), \mathrm{TsOH} \cdot \mathrm{H}_{2} \mathrm{O}, 2{ }^{\circ} \mathrm{C}$.

8,17-Olefinic compounds of $\mathbf{7}$ to $\mathbf{1 2}$ and their corresponding deprotected derivatives $\mathbf{1 3}$ to 18 were synthesized as previously published [32-34]. Briefly, the acetonide-protected $14 \alpha$ and $14 \beta$ analogues of andrographolide [34] were reacted with various 8-hydroxyquinoline 
derivatives in Mitsunobu conditions, yielding the analogues 7-12, which were subsequently deprotected by hydrolysis, giving the analogues 13-17 (Scheme 1).

The analogues of 17-hydro-9-dehydro andrographolide (27-32 and 33-38) were prepared as presented in Scheme 2. Firstly, 3,19-acetonylidene andrographolide (2) was 4-nitrobenzoylated by acylation or Mitsunobu reaction to form 19 or 20, respectively. The key step is to isomerize the 8,17-double bond of $\mathbf{1 9}$ or $\mathbf{2 0}$ into 8,9-double bond of $\mathbf{2 1}$ or 22 by $85 \% \mathrm{H}_{3} \mathrm{PO}_{4}$, which removed the acetonide protection. After re-protection as 3,19acetonylidene, the 4-nitrobenzoyl group was removed to form the two key intermediates $25(14 \alpha)$ and $26(14 \beta)$, which then reacted with the 8-hydroxyquinoline derivatives 4, 5, and 6 to yield the 3,19-acetonylidene-protected analogues 27 to 32. Deprotection of the 3,19-acetonylidene group afforded the 3,19-diol analogues 33 to 38 .

\subsection{Screening of Andrographolide Derivatives for $S A P P \alpha$ Production and $S A P P \alpha / \beta A P P$ Ratio}

We then investigated the effect of andrographolide and its 24 derivatives for their ability to promote the secretion of the $\beta$ APP-derived sAPP $\alpha$ metabolite in cultured naive SH-SY5Y human neuroblastoma cells. As a first step, we chose to treat the cells for $24 \mathrm{~h}$ with $1 \mu \mathrm{M}$ of the compounds (andrographolide, the 12 derivatives of the 8,17-olefinic series (8,17-double bond) and the 12 derivatives of the 9-dehydro-17-hydro series $(8,9-$ olefen/double bond)) and we used both sAPP $\alpha$ production and the sAPP $\alpha / \beta \mathrm{APP} / \beta$-actin ratio as a read out for comparison with controls (duplicate).

The results showed that four derivatives $(28,31$, and their corresponding deprotected forms 34 and 37) of the 9-dehydro-17-hydro series were able to increase sAPP $\alpha$ production by a factor greater than two when compared to controls (Figure 1A,B), while treatment of cells with 9 and 31 led to a 2.5-fold augmentation of the $\mathrm{sAPP} \alpha / \beta \mathrm{APP} / \beta$-actin ratio (Figure $1 C$ ). It is noted that most of the tested andrographolide analogues were more active than andrographolide in increasing $\operatorname{sAPP} \alpha$ production (Figure $1 \mathrm{~A}, \mathrm{~B}$ ) and $\mathrm{sAPP} \alpha / \beta \mathrm{APP}$ ratio (Figure 1C). Specifically, eight compounds $(\mathbf{8}, \mathbf{1 1}-16$, and 18) of the 8,17-double bond series and ten compounds (28-34 and 36-38) of the 8,9-double bond series increased SAPP $\alpha$ production when compared to andrographolide (Figure 1A,B), while nine compounds $(8,9,11,12-16$, and 18) of the 8,17-double bond series and eight $(28,30,31,33,34$, and 36-38) of the 8,9-double bond series displayed higher SAPP $\alpha / \beta$ APP ratio than andrographolide (Figure 1C). Particularly, the $14 \alpha-\left(2^{\prime}\right.$-methyl- $5^{\prime}, 7^{\prime}$-dichloro- $8^{\prime}$-quinolyloxy)-3,19acetonylidene-8,17-olefinic analogue 31 showed the highest sAPP $\alpha$ secretion (Figure 1A,B) and the second highest sAPP $\alpha / \beta A P P$ ratio (Figure $1 C)$. In contrast, $14 \alpha-\left(5^{\prime}, 7^{\prime}\right.$-dichloro- $8^{\prime}$ quinolyloxy)-8,9-olefin-3,19-diol 35 exhibited the lowest $\mathrm{sAPP} \alpha$ secretion rate (Figure 1A,B) and $\mathrm{sAPP} \alpha / \beta \mathrm{APP}$ ratio (Figure $1 \mathrm{C}$ ).

Moreover, both $14 \alpha-\left(2^{\prime}\right.$-methyl-8'-quinolyloxy)-3,19-acetonylidene compound 7 and its 8,9-double bond counterpart 27 displayed much lower sAPP $\alpha$ production (Figure $1 \mathrm{~A}, \mathrm{~B}$ ) and sAPP $\alpha / \beta$ APP ratio (Figure $1 C$ ) than their corresponding $14 \beta$ compounds 8 and 28 . Meanwhile, the 3,19-diols $13(14 \alpha)$ and $14(14 \beta)$ are more able than the 3,19-protected compounds 7 and 8 to increase sAPP $\alpha$ production (Figure $1 \mathrm{~A}, \mathrm{~B}$ ) and $\mathrm{sAPP} \alpha / \beta \mathrm{APP}$ ratio (Figure 1C) while the $14 \beta-8,9-$ olefinic-3,19-diol 34 is superior to its $14 \alpha$ counterpart 33 in augmenting both $\mathrm{sAPP} \alpha$ production (Figure $1 \mathrm{~A}, \mathrm{~B}$ ) and the sAPP $\alpha / \beta \mathrm{APP}$ ratio (Figure $1 \mathrm{C}$ ).

Among the $5^{\prime}, 7^{\prime}$-dichloro- $8^{\prime}$-quinolyloxy series, the three 8,17-olefinic compounds, $14 \alpha-3,19$-acetonylidene $9,3,19$-diols $15(14 \alpha)$ and $16(14 \beta)$ are similarly active and superior to their 14 $\beta$-3,19-acetonylidene-8,17-olefinic 10, 14 $\alpha$-3,19-acetonylidene-8,9-double bond 29 and $14 \alpha-3,19$-acetonylidene-8,9-olefinic 35 counterparts in both promoting sAPP $\alpha$ secretion (Figure $1 \mathrm{~A}, \mathrm{~B}$ ) and increasing the $\mathrm{sAPP} \alpha / \beta \mathrm{APP}$ ratio (Figure $1 \mathrm{C}$ ). In addition, it appeared that the $14 \beta-3,19$-acetonylidene-8,9-olefinic compound $\mathbf{3 0}$ is less active than its corresponding diol 36 in promoting sAPP $\alpha$ secretion (Figure $1 \mathrm{~A}, \mathrm{~B}$ ) and increasing the sAPP $\alpha / \beta \mathrm{APP}$ ratio (Figure 1C). In this series, 36 is the most active sAPP $\alpha$ secretion inducer (Figure $1 \mathrm{~A}, \mathrm{~B}$ ) while 9,16 , and 36 are the compounds most capable of increasing the $\mathrm{SAPP} \alpha / \beta \mathrm{APP}$ ratio (Figure 1C). 
A
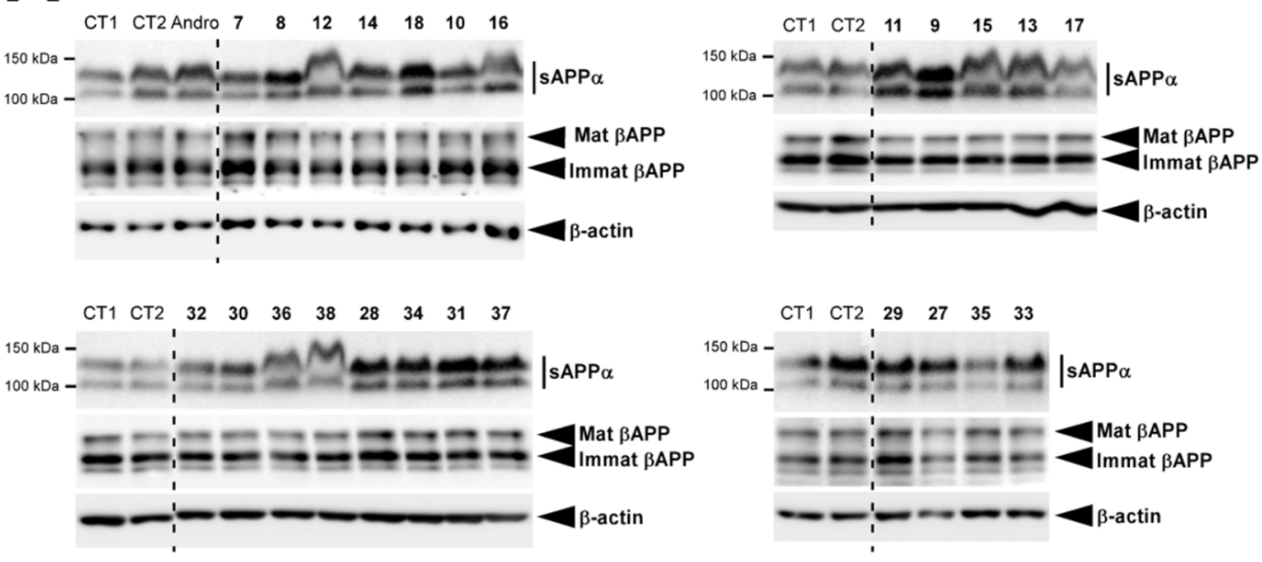

B

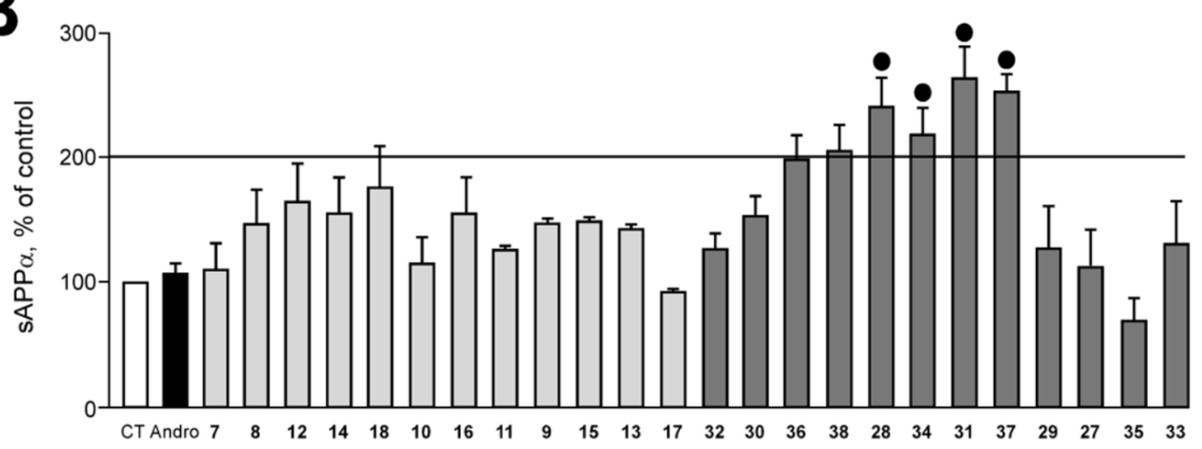

C

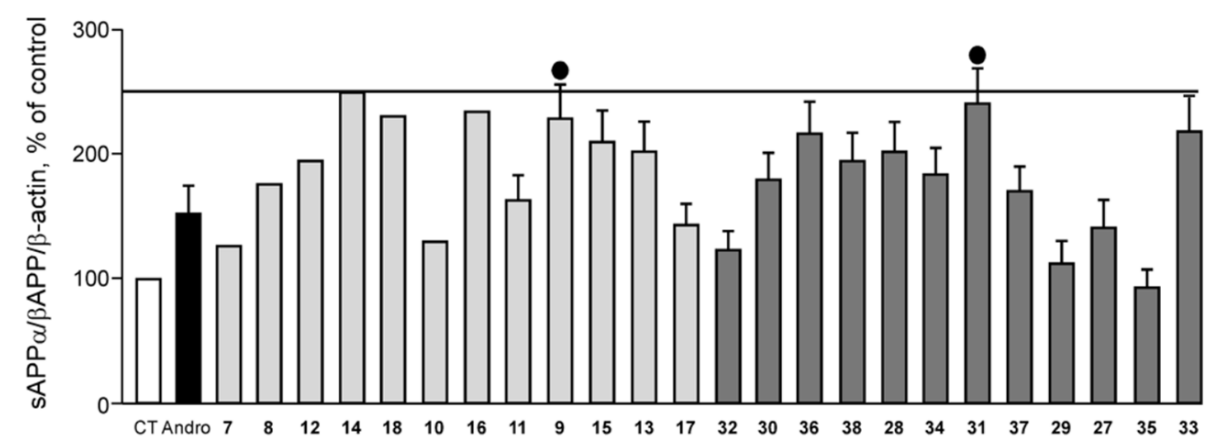

Figure 1. Screening of andrographolide and andrographolide derivatives for sAPP $\alpha$ secretion, $\beta$ APP protein levels, and the ratio SAPP $\alpha / \beta$ APP in SH-SY5Y cells. (A) illustrates the Western blot analysis of the screening. Bars in (B) (sAPP $\alpha$ production) and (C) (ratio of sAPP $\alpha$ to $\beta$ APP normalized with $\beta$-actin) correspond to the densitometric analyses, are expressed as a percentage of control (white bars, non-treated cells) and are the average of the comparison with two controls. The black circles indicate compounds selected for further characterization. The hatched black line in (A) indicates a splicing of the original gels.

Now regarding the $14-\left(2^{\prime}\right.$-methyl-5', $7^{\prime}$-dichloro- $8^{\prime}$-quinolyloxy)-8,17-olefinic analogues, the $14 \alpha-3,19$-acetonylidene compound 11 and its 3,19-diol analogue 17 were less active than their respective $14 \beta 12$ and 18 counterparts in both sAPP $\alpha$ secretion (Figure $1 \mathrm{~A}, \mathrm{~B}$ ) and sAPP $\alpha / \beta$ APP ratio (Figure $1 C)$. On the other hand, the $14 \alpha-\left(2^{\prime}\right.$-methyl- $-5^{\prime}, 7^{\prime}-$ dichloro- $8^{\prime}-$ quinolyloxy)-8,9-olefinic compound 31 and its 3,19-diol analogue 37 displayed the highest $\mathrm{sAPP} \alpha$ secretion rate (Figure $1 \mathrm{~A}, \mathrm{~B}$ ) and a relatively high $\mathrm{SAPP} \alpha / \beta \mathrm{APP}$ ratio (Figure $1 \mathrm{C}$ ). However, the corresponding 14 $\beta-3,19$-acetonylidene compound 32 and its diol 38 behaved 
in opposite ways with 32 having a much lower ability than 38 to increase $\mathrm{SAPP} \alpha$ secretion (Figure $1 \mathrm{~A}, \mathrm{~B}$ ) and the $\mathrm{APP} \alpha / \beta \mathrm{APP}$ ratio (Figure $1 \mathrm{C}$ ).

Overall, these results suggest that an optimal combination of 8,9 -double bond or 8,17 -double bond, substitution at quinolone, $14 \alpha$ or $14 \beta$, and 3,19-free diol or protection will benefit the enhancement of SAPP $\alpha$ production. As a whole, based on the screening results and structure-activity consideration, we undertook to focus on 9, 28, 31, 34, and 37 for further characterization, using andrographolide as the reference compound.

\subsection{Further Characterization of Andrographolide Derivatives 9, 28, 34, 31, and $\mathbf{3 7}$}

The results obtained following a consistent number of independent experiments ( $\mathrm{n} \geq 6$ when compared with $\mathrm{n}=2$ for the initial screening step) first showed that 31 and $37(1 \mu \mathrm{M})$ significantly induce sAPP $\alpha$ secretion (Figure $2 \mathrm{~A}, \mathrm{~B})$. Secondly, none of the compounds significantly altered $\beta$ APP immunoreactivity (Figure $2 \mathrm{~A}, \mathrm{C}$ ), thereby ruling out an effect on $\beta$ APP expression or maturation and rather suggesting that they genuinely control $\beta$ APP processing. The additional measurement of the $\mathrm{sAPP} \alpha / \beta \mathrm{APP} / \beta$-actin ratio further indicated that all the selected derivatives including andrographolide itself were able to significantly increase this ratio although to different degrees (Figure 2D).
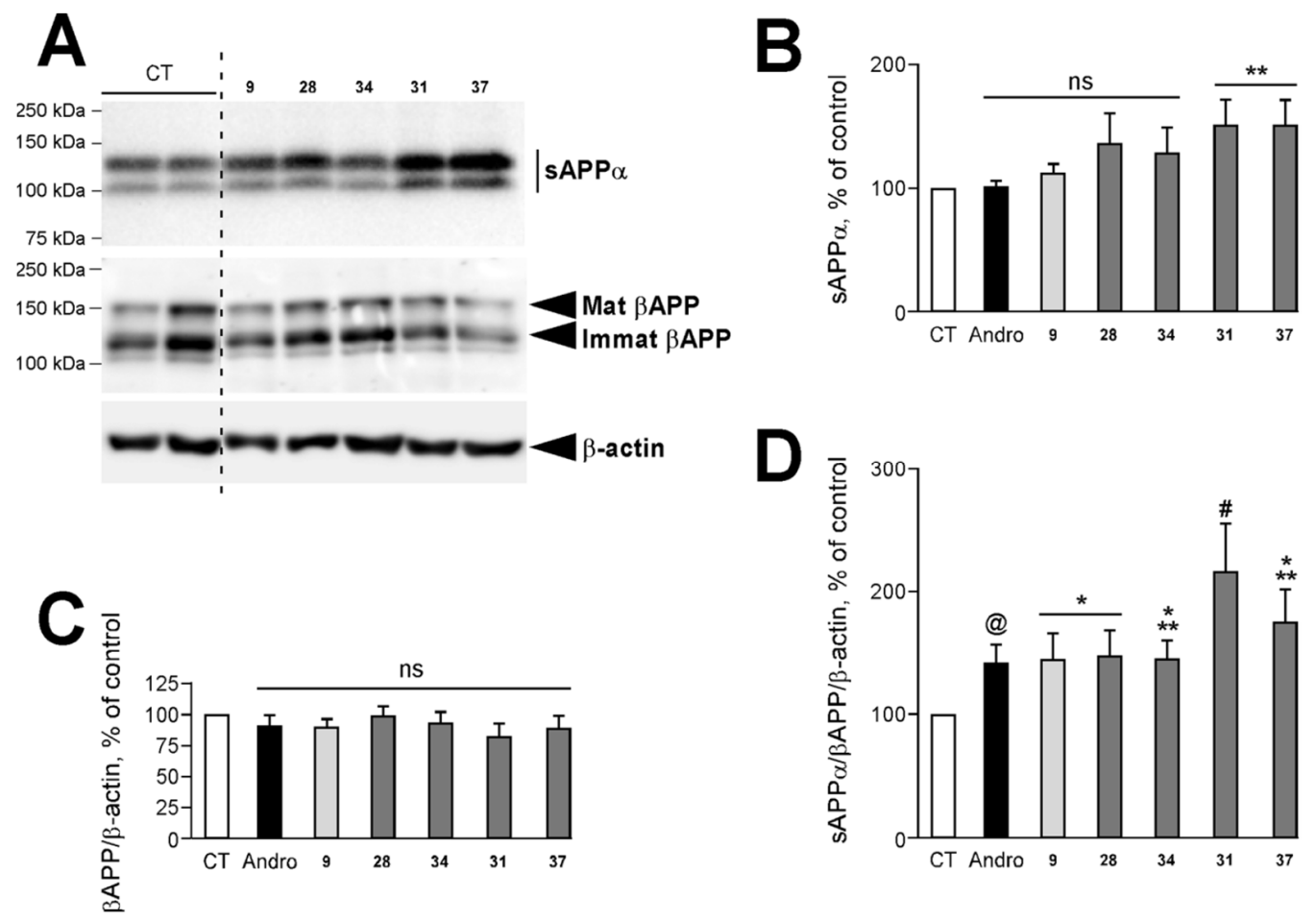

Figure 2. Effect of andrographolide and the selected andrographolide derivatives on SAPP $\alpha$ secretion, $\beta A P P$ protein levels and the ratio sAPP $\alpha / \beta$ APP in SH-SY5Y cells. (A) illustrates one representative gel. Bars in (B) (sAPP $\alpha$ production), (C) ( $\beta$ APP immunoreactivity normalized with $\beta$-actin), and (D) (ratio of $\operatorname{sAPP} \alpha$ to $\beta \mathrm{APP}$ normalized with $\beta$-actin) correspond to the densitometric analyses, are expressed as a percentage of control (white bars, non-treated cells), and are the means $\pm \mathrm{SE}$ of 6 to 10 independent determinations. ${ }^{*} p<0.05 ;{ }^{* *} p<0.03$; ${ }^{* * *} p<0.02$; ${ }^{*} p<0.01$; $@ p<0.001$; ns, no statistical difference. The hatched black line in $(\mathrm{A})$ indicates a splicing of the original gels.

\subsection{Full Characterization of Andrographolide Derivatives 9, 31, and $\mathbf{3 7}$}

\subsubsection{Effect of Derivatives 9, 31, and 37 on Cell Survival}

In light of these results, we decided to reduce our field of investigation to 9, 31, and 37. At this stage, it was important to demonstrate that these compounds are not inherently toxic. For this purpose, we measured the survival rate of SH-SY5Y cells following a $24 \mathrm{~h}$ treatment at concentrations ranging from $100 \mathrm{nM}$ to $10 \mu \mathrm{M}$ with the MTT assay. In fact, no 
notable changes were observed whatever the compound and the concentrations considered (Figure 3), clearly indicating that none of them are toxic under our experimental conditions.

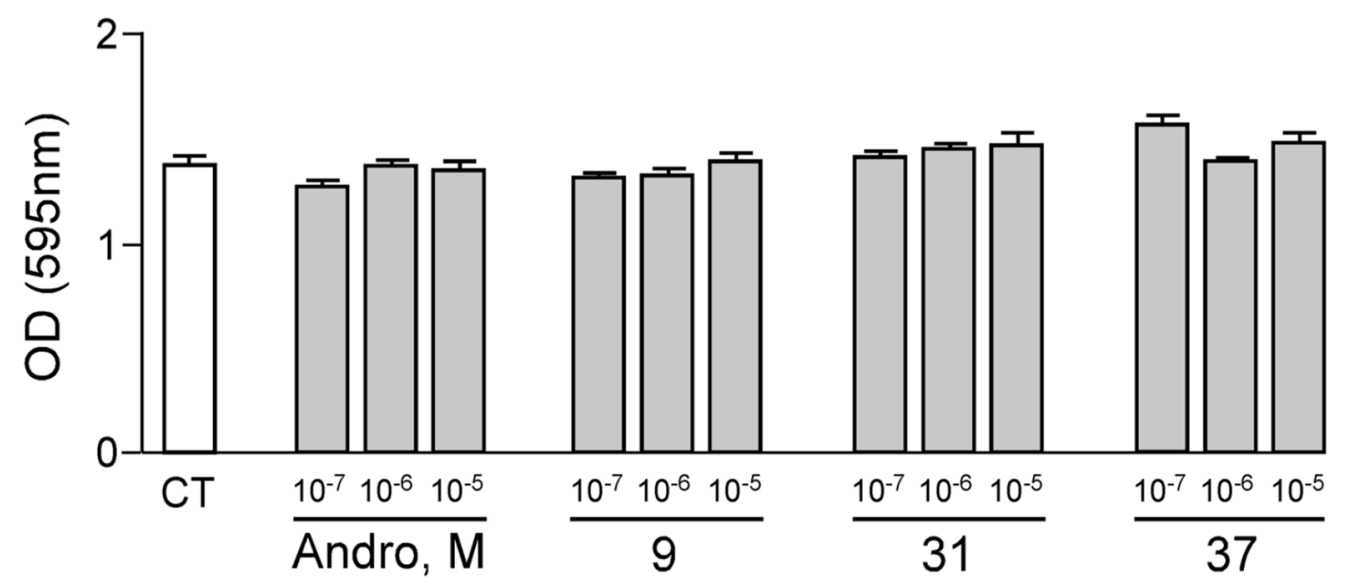

Figure 3. Andrographolide and compounds 9, 31, and 37 do not trigger toxicity in SH-SY5Y cells. Cells were incubated without (control, white bar) or with three concentrations (100 nM, $1 \mu \mathrm{M}$, and $10 \mu \mathrm{M}$ ) of the four compounds for $24 \mathrm{~h}$ and cell viability was determined with the MTT assay. The results are expressed as the mean of quadruplicates and no statistical difference were observed.

\subsubsection{Dose-Dependent Effect of Derivatives 9, 31, and 37 on sAPP $\alpha$ Production, $\beta$ APP} Protein Levels, and sAPP $\alpha / \beta$ APP Ratio

Following the screening phase carried out at one single concentration $(1 \mu \mathrm{M})$, we then examined the ability of the selected compounds to stimulate $\operatorname{APP} \alpha$ at lower concentrations and in a dose-dependent manner in SH-SY5Y cells. Although an increasing trend was observed for both andrographolide and 9, we could not establish statistically significant differences with controls (Figure 4A). Nevertheless, in addition to the fact that 31 and 37 were triggering a significant increase in $\mathrm{sAPP} \alpha$ production at $1 \mu \mathrm{M}$ (Figure $4 \mathrm{~A}$ ) as previously observed (see Figure 2), we showed that 37 is also effective at $10 \mathrm{nM}$ and $100 \mathrm{nM}$ concentrations (Figure 4A). Parallel analysis of $\beta$ APP protein levels showed no significant variation in $\beta$ APP immunoreactivity under any conditions (Figure $4 \mathrm{~B})$. The concomitant measurement of the $\operatorname{sAPP} \alpha / \beta \mathrm{APP} / \beta$-actin ratio showed in addition that the four compounds increased it significantly at the highest concentrations (100 $\mathrm{nM}$ to $1 \mu \mathrm{M}$ ) (Figure 4C). Following the demonstration of the superior efficiency of compound 37 in inducing the production of $\operatorname{sAPP} \alpha$ and in order to show that these effects are not restricted to a cell type but rather represent a ubiquitous phenomenon, we conducted the same experiments in human cells HEK293. The results showed that 37 produced effects similar and even superior to those observed in SH-SY5Y cells, namely an increase in sAPP $\alpha$ production and in the $\mathrm{APP} \alpha / \beta \mathrm{APP} / \beta$-actin ratio at all concentrations tested (Figure $4 \mathrm{D}$, upper and lower panels, respectively). The additional observation that $\mathbf{3 7}$ also significantly reduced $\beta$ APP protein levels at the same concentrations in HEK293 cells (Figure 4D, middle panel) most likely reflects some depletion of the substrate due to higher metabolic activity when compared to the SH-SY5Y cell line. 


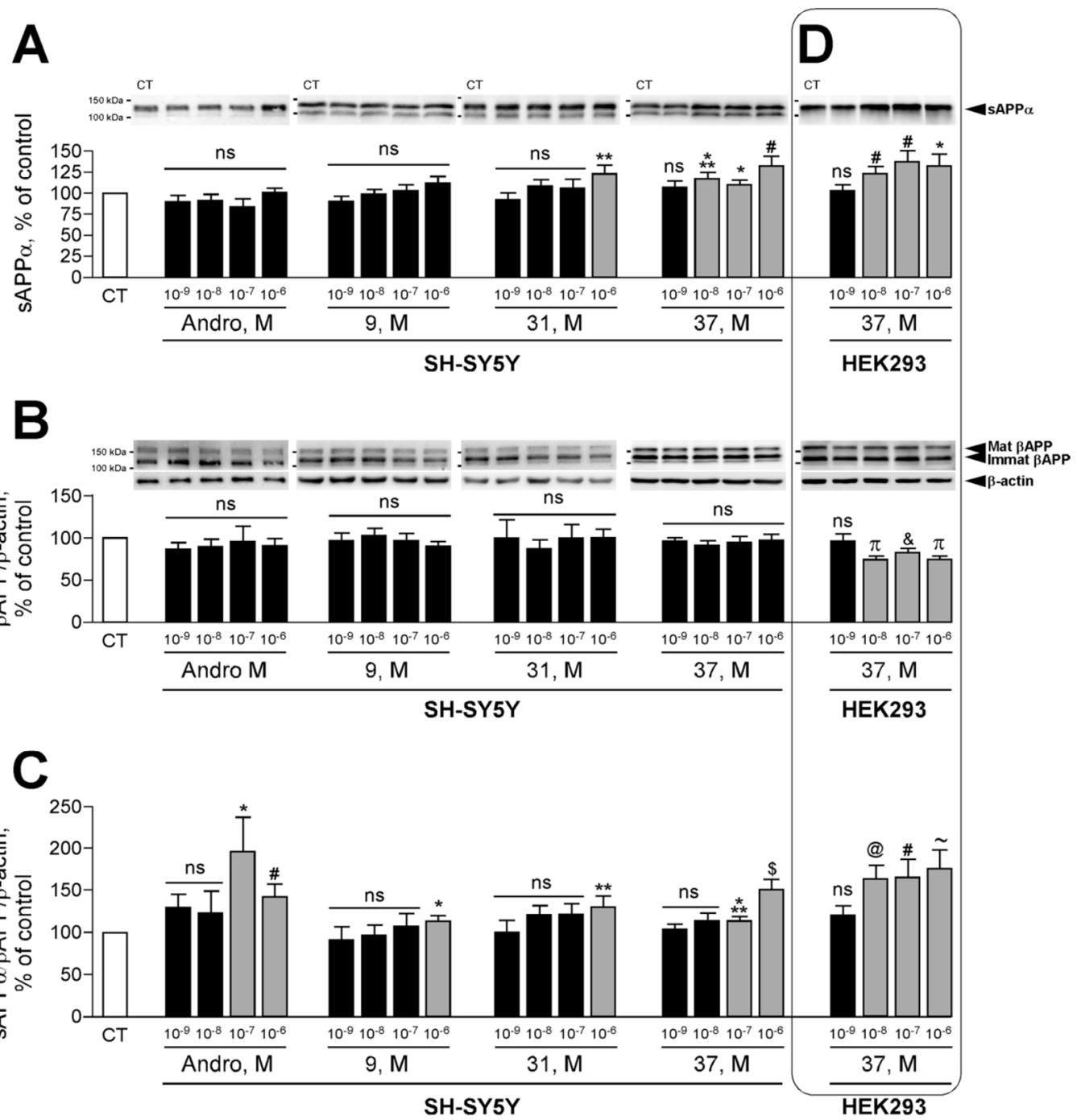

Figure 4. Effects of andrographolide and compounds 9, 31, and 37 at different doses on sAPP $\alpha$ secretion, $\beta$ APP protein levels, and the ratio sAPP $\alpha / \beta$ APP in human cells. Data presented in (A) (sAPP $\alpha$ production), (B) ( $\beta$ APP immunoreactivity normalized with $\beta$-actin), and (C) (ratio of sAPP $\alpha$ to $\beta$ APP normalized with $\beta$-actin) are from experiments carried out in SH-SY5Y cells while data in (D) correspond to the results obtained for 37 in HEK293 cells. All bars are the densitometric analyses, are expressed as a percentage of control (white bars, non-treated cells) and are the means \pm SE of 9 to 20 independent determinations. ${ }^{*} p<0.05 ;{ }^{* *} p<0.03 ;{ }^{* * *} p<0.02 ;{ }^{*} p<0.01 ; \sim p<0.003$; \& $p<0.002$; @ $p<0.001 ;{ }^{\$} p<0.0002 ; \pi p<0.0001$ (gray bars); ns, no statistical difference (black bars). The upper parts of each panel illustrate representative gels.

\subsubsection{Effect of Derivatives 9, 31, and $\mathbf{3 7}$ on ADAM10 and BACE1 Protein and mRNA} Levels

Based on these results, we then wanted to determine whether these compounds were capable of influencing the expression of the main $\alpha$-secretase activity ADAM10 and of the $\beta$-secretase BACE1.

Firstly, the Western blot analyse of ADAM10 (Figure 5A) and BACE1 (Figure 5B) in SH-SY5Y cells did not detect any significant changes between the control conditions and those where the cells were treated with the four compounds at concentrations ranging from $1 \mathrm{nM}$ to $1 \mu \mathrm{M}$. These results were then confirmed for 37 in HEK293 cells (Figure 5C). Because protein level measurement results from transcriptional, translational, and posttranslational events, we undertook to examine the genuine transcriptional effect of the four compounds $(1 \mu \mathrm{M})$ by real time qPCR in both SH-SY5Y and HEK293 cells. The results 
indicated a slight but significant increase in ADAM10 mRNA levels when cells were treated with $1 \mu \mathrm{M}$ of 31 and 37 (SH-SY5Y) or 9 (HEK293) (Figure 5D), while no significant change in BACE1 mRNA levels was detected (Figure 5E).
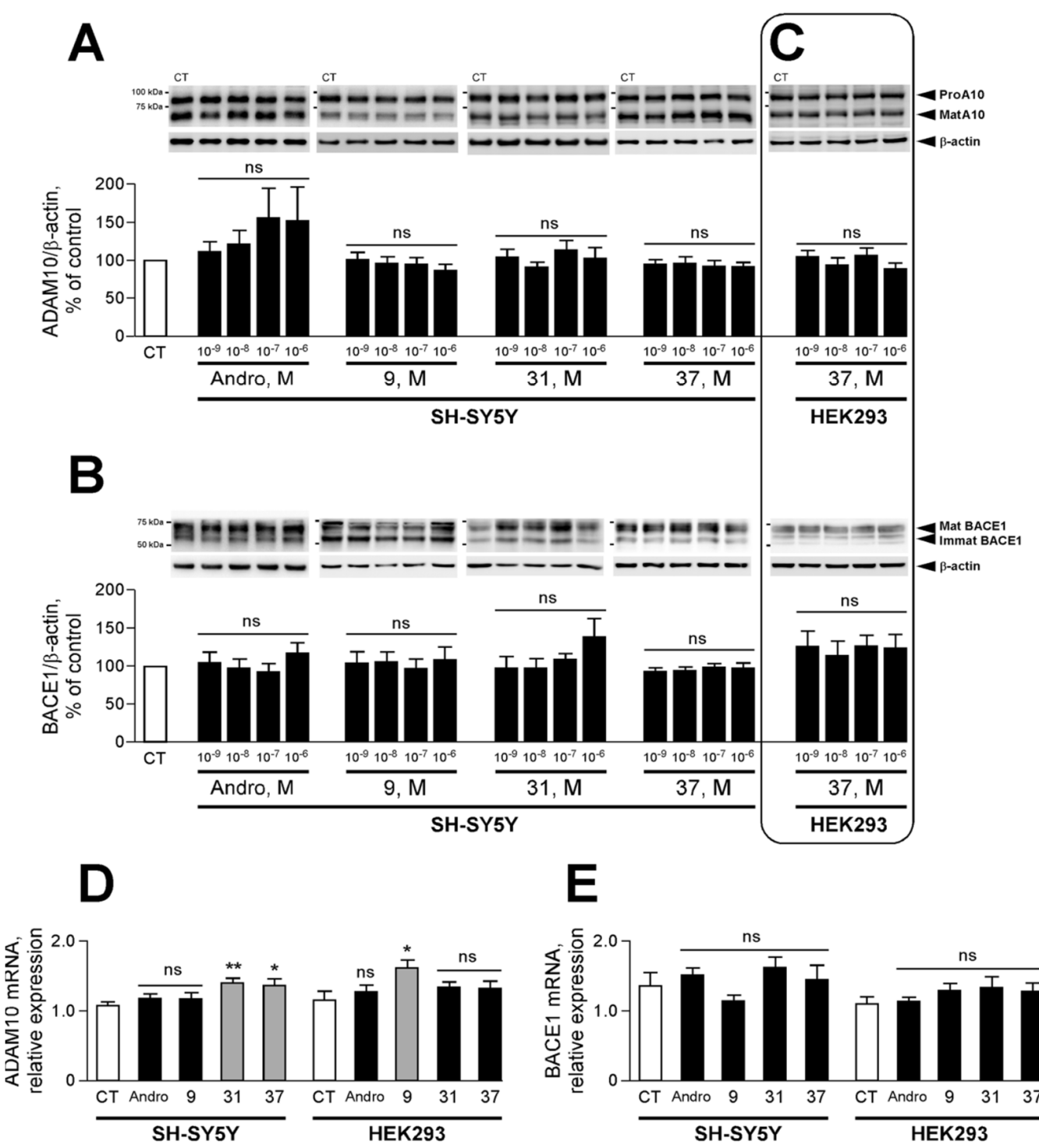

Figure 5. Effects of andrographolide and compounds 9, 31, and 37 on ADAM10 and BACE1 expression in human cells. ADAM10 and BACE1 protein (A-C) and mRNA $(\mathbf{D}, \mathbf{E})$ levels were measured (by Western blot and real-time qPCR, respectively) in the indicated cell lines following treatment without (control, white bar) or with various concentrations of the compounds ( $1 \mathrm{nM}$ to $1 \mu \mathrm{M})$. Bars are the densitometric analyses, are expressed as a percentage of control (white bars, non-treated cells), and are the means \pm SE of 11 to 18 (Western blots) and 4 (qPCR) independent determinations. ${ }^{*} p<0.03$; ** $p<0.01$ (gray bars); ns, no statistical difference (black bars). The upper parts of panels A and B illustrate representative gels.

This set of data suggests transcriptional up-regulation of the $\alpha$-secretase ADAM10 as a minor although possibly involved mechanism in the observed beneficial effect of these compounds on $\beta$ APP metabolism.

We finally subjected andrographolide and the three derivatives to a thorough characterization aimed at evaluating their effect on the catalytic activities of $\alpha$ - and $\beta$-secretases, which compete for $\beta$ APP processing, thereby tightly controlling the balancing between the amyloidogenic and the non-amyloidogenic pathways. 


\subsubsection{Effect of Derivatives 9, 31, and 37 on $\alpha$-Secretase Catalytic Activity}

In a first set of experiments, we examined the impact of increasing concentrations (10 $\mathrm{nM}$ up to $10 \mu \mathrm{M}$ for andrographolide and $1 \mathrm{nM}$ to $1 \mu \mathrm{M}$ for compounds 9, 31, and 37) of the four compounds on the $\alpha$-secretase activity by measuring the phenanthroline-sensitive hydrolysis of the fluorimetric JMV2770 substrate by cultured SH-SY5Y cells.

Our results indicated that andrographolide slightly and dose-dependently enhances the JMV2770-hydrolyzing activity, 9 displaying such capability only at $10 \mathrm{nM}$ while $\mathbf{3 1}$ and 37 remain inert in this paradigm (Figure 6A). Andrographolide and 9 were subsequently submitted to the same assay in HEK293 where they also significantly contributed to a moderate stimulation of the $\alpha$-secretase activity, although showing a slightly different pattern when compared to SH-SY5Y cells (Figure 6B).

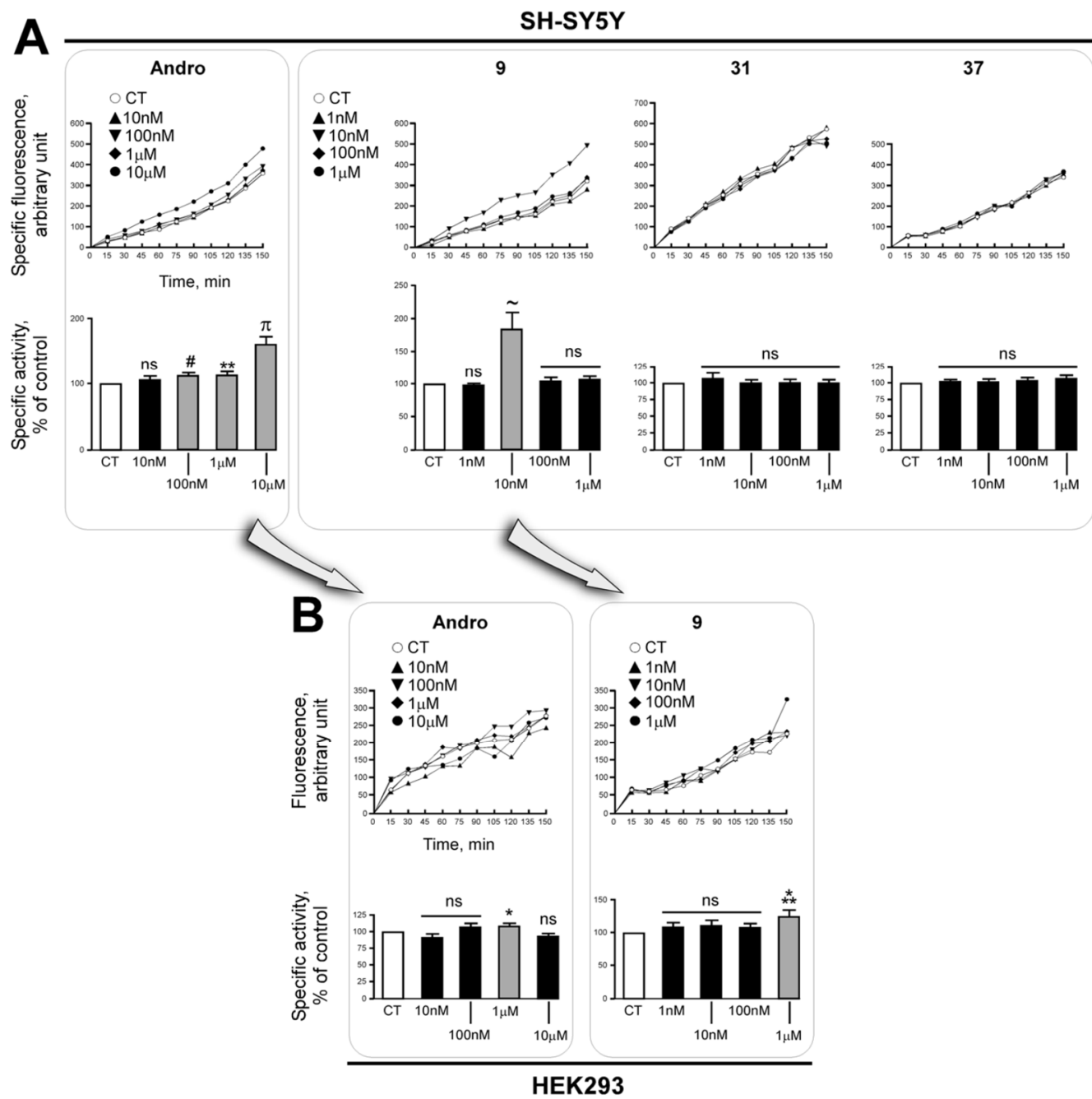

Figure 6. Effects of andrographolide and compounds 9, 31, and 37 on the $\alpha$-secretase catalytic activity in human cells. (A) The $\alpha$-secretase catalytic activity (phenanthroline-sensitive hydrolysis of the fluorimetric substrate JMV2770) was measured on cultured SH-SY5Y cells in the absence (control, white circle/white bar) or in the presence of various concentrations of the compounds (10 $\mathrm{nM}$ to $10 \mu \mathrm{M}$ for andrographolide; $1 \mathrm{nM}$ to $1 \mu \mathrm{M}$ for compounds 9, 31, and 37). (B) Experiments carried out with andrographolide and 9 under the same conditions on cultured HEK293 cells. The curves represent the mean specific fluorescence (from 2 to 3 independent experiments including two controls each) while bars in histograms are expressed as a percentage of control (white bars, non-treated cells) calculated from the linear parts of the curves (initial velocity) and are the means \pm SE of 8 to 16 independent determinations. ${ }^{*} p<0.05 ;{ }^{* *} p<0.03$; ${ }^{* * *} p<0.02$; ${ }^{*} p<0.01 ; \sim p<0.003 ;{ }^{\pi} p<0.0001$ (gray bars); ns, no statistical difference (black bars). 


\subsubsection{Effect of Derivatives 9, 31, and $\mathbf{3 7}$ on $\beta$-Secretase Catalytic Activity}

Another important aspect of this study was to determine if these compounds could behave as inhibitors of the amyloidogenic $\beta$-secretase catalytic activity. Taking advantage of a well-characterized BACE1-selective fluorimetric assay, we have first measured the effect of the four molecules, at the same concentrations used for the $\alpha$-secretase assay, on the JMV1197-sensitive hydrolysis of the fluorimetric JMV2236 substrate in SH-SY5Y cell extracts at acidic $\mathrm{pH}$. We showed a capability of all the compounds to reduce BACE1 activity, 31 and 37 operating the most efficiently and in a dose-dependent manner (Figure 7A).

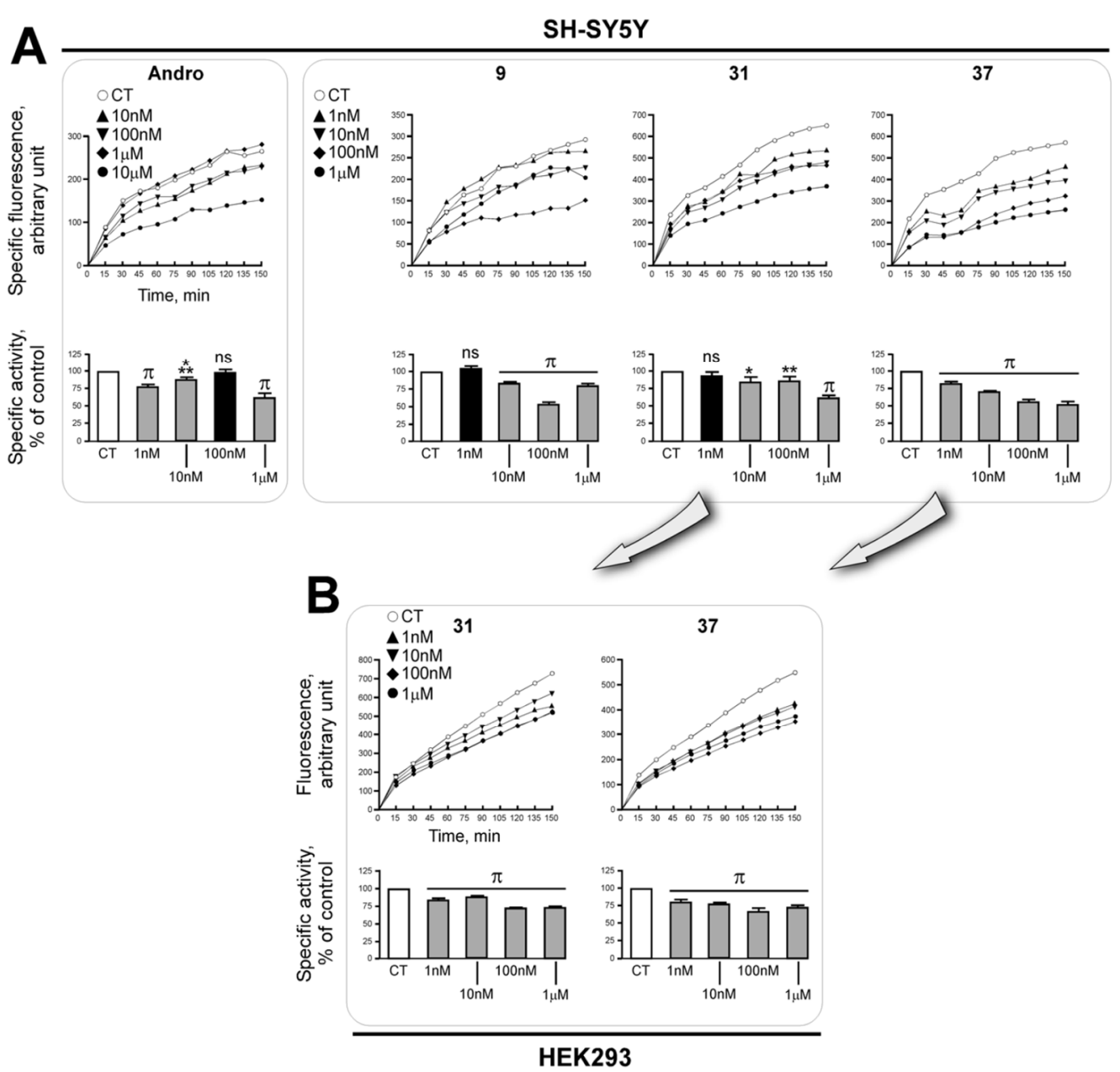

Figure 7. Effects of andrographolide and compounds 9, 31, and 37 on the $\beta$-secretase catalytic activity in human cells. (A) The $\beta$-secretase catalytic activity (JMV1197-sensitive hydrolysis of the fluorimetric substrate JMV2236) was measured in SH-SY5Y cell extracts in the absence (control, white circle/white bar) or in the presence of various concentrations of the compounds ( $1 \mathrm{nM}$ to $1 \mu \mathrm{M}$ for andrographolide; $1 \mathrm{nM}$ to $1 \mathrm{mM}$ for compounds 9, 31, and 37). (B) Experiments carried out with 31 and 37 under the same conditions in HEK293 cell extracts. The curves represent the mean specific fluorescence (from 2 to 3 independent experiments including two controls each) while bars in histograms are expressed as a percentage of control (white bars, non-treated cells) calculated from the linear parts of the curves (initial velocity) and are the means \pm SE of 6 to 15 independent determinations. ${ }^{*} p<0.05 ;{ }^{* *} p<0.03 ;{ }^{* * *} p<0.02 ;{ }^{\pi} p<0.0001$ (gray bars); ns, no statistical difference (black bars).

The data obtained with $\mathbf{3 1}$ and $\mathbf{3 7}$ were then reproduced with HEK293 cell extracts, thereby confirming the genuine ability of these two andrographolide analogues to potently block the $\beta$-secretase catalytic activity (Figure 7B). It should be noted here that the inhibitory effects of the compounds on the $\beta$-secretase activity seem to be more pronounced than 
their capability to stimulate the $\alpha$-secretase activity. From the fact that compound 9 of the 8,17 -olefinic series possesses anti-BACE1 activity, it is suggested that the $5^{\prime}, 7^{\prime}$-dichloro$8^{\prime}$-hydroxyquinolyloxy moiety is important for BACE1 inhibition. As the $2^{\prime}$-methyl-5', $7^{\prime}$ dichloro- $8^{\prime}$-hydroxyquinolyloxy derivatives 31 and 37 are potent BACE1 inhibitors, this particular structure might interact in a more efficient way with the BACE1 catalytic site. Finally, the observation that $\mathbf{3 1}$ and $\mathbf{3 7}$ are the most potent $\beta$-secretase inhibiting factors in this study, suggests that the 8,9-double bond in the 9-dehydro-17-hydro series is an important feature for a proper inhibition of this activity.

\section{Discussion}

$\mathrm{AD}$ is a yet incurable neurodegenerative disorder characterized by loss of memory and cognition. The reason why available medical treatments are still incapable of curing $\mathrm{AD}$ symptoms efficiently mostly resides in the fact that $\mathrm{AD}$ is a complex and multifactorial pathology. Over the past decades, a huge effort, although in vain, has been made to develop novel synthetic drugs with disease-modifying properties and few side effects [35]. Hence, compounds extracted from natural sources are constantly gaining popularity in $\mathrm{AD}$ treatment with the notion of preventive rather than curative intervention against the disease being increasingly considered.

In this context, beside its previously reported effects on viral infection [36], bacterial infection [37], cancer [38], metabolic syndromes [39], and inflammation [40], thereby making this molecule a multi-targeting agent [41], andrographolide has also been interestingly established as a promising candidate in neuropharmacology as it shows diverse potent therapeutic effects against various neurological disorders [29], such as brain ischemic stroke [42], multiple sclerosis [43], Parkinson's disease [44], and Alzheimer's disease [19].

Regarding AD and on a mechanistic point of view, andrographolide most likely conveys some anti-AD effects via its well-established antioxidant [45] and NFKB inhibitory and anti-inflammatory [46] properties as illustrated for instance by the fact that andrographolide inhibits $A \beta_{1-42}$-induced production of neuroinflammatory mediators in microglia $[13,14]$. However, whether it could regulate the processing of $\beta$ APP through the control of $\beta$ APP-cleaving secretases was still an unanswered question. Here, we first identified andrographolide as well as some chemically modified andrographolide analogues as regulators of $\beta \mathrm{APP}$ processing in cultured human cell lines using sAPP $\alpha$ production as a read-out. This metabolite with beneficial properties arises from the cleavage of $\beta$ APP by the non-amyloidogenic $\alpha$-secretase activity. Because $\alpha$-secretase and $\beta$-secretase, the amyloidogenic rate-limiting initiator of amyloid peptide production, work competitively regarding $\beta$ APP processing as evidenced by the inverse correlation between $\operatorname{APP} \alpha$ and $\mathrm{A} \beta$ productions under both $\alpha$-secretase activation or $\beta$-secretase inhibition $[47,48]$, any increase in $\mathrm{SAPP} \alpha$ production can result from either an activation of $\alpha$-secretase or an inhibition of $\beta$-secretase (that disrupts SAPP $\alpha$ integrity by cleaving inside its sequence), or both. We therefore undertook to study the effect of andrographolide, 9, 31, and 37, all initially identified on the basis of their ability to induce the production of $\operatorname{sAPP} \alpha$, on the catalytic activities of $\alpha$ - and $\beta$-secretase by means of specific fluorimetric assays. This allowed us to establish that the four compounds indeed regulate these activities although to different degrees and that $\mathbf{3 1}$ and $\mathbf{3 7}$ behave as potent $\beta$-secretase inhibitors. It has to be underlined here that their efficiency at submicromolar concentrations lays the groundwork for the future production of highly potent derivatives that could serve as a basis for their therapeutic use. Moreover, the confirmation of the results in HEK293 cells suggests that the effects observed are probably ubiquitous and not restricted to one cell type.

Importantly, studies carried out in animals have shown that andrographolide does not trigger toxicity in the liver and the kidney of rat [49] and does not alter body and organ weight, inflammatory responses, hematological parameters, and mortality in mice [50]. These data therefore established andrographolide as a relatively safe compound in respect to toxicological side effects. Moreover, andrographolide easily passes the blood-brain barrier and distributes into different brain regions [51]. However, restricted bioavailability 
due to its poor solubility and relatively short half-life obviously limits its clinical application and numerous semi-synthetic transformations were performed in order to improve its physiochemical properties and stability [52,53].

Considering that quinoline is also a pharmacophore group for neuroprotection $[28,30$, 31], we envisaged that our published active 14-quinolyloxy derivatives of andrographolide against Zika and dengue viruses [32,33] and bacteria [54] possibly have anti-AD activity. Moreover, in addition to andrographolide itself [26,29,36,55], some of its 9-dehydro-17hydro analogues have increased neuroprotective properties [12] and are more efficient against angiogenesis $[56,57]$ than its 8,17 -olefinic counterpart. These results led us to explore whether 14-aryloxy-9-dehydro-17-hydro analogues also possess a higher capability to inhibit BACE1 activity than the 8,17-olefinic ones. Our results confirmed the concept that 14-quinolyloxy modification or combination of 14-quinolyloxy and 9-dehydro-17hydro modifications on andrographolide benefits for neuroprotection and will lead to the discovery of more potent and druggable anti-AD compounds.

Overall, our original findings that andrographolide derivatives display both pro$\alpha$-secretase and anti- $\beta$-secretase properties open the way to the possible development, hitherto not explored, of molecules of natural origin capable of acting in a doubly beneficial manner on the metabolism of $\beta$ APP and representing a new class of factors to be developed as a therapeutic tool aimed at combating Alzheimer's disease. The design, synthesis and testing of new chemically modified andrographolide-derived compounds aimed at obtaining highly potent $\alpha$ - and $\beta$-secretases regulating molecules is currently being carried out in our laboratories.

\section{Materials and Methods}

\subsection{Materials}

DMEM, fetal bovine serum (FBS), and penicillin-streptomycin mix (Pen/Strep) were from Invitrogen (Carlsbad, CA, USA). Tris buffer and glycine were from VWR Amresco lifesciences (Solon, CA, USA). Polyclonal anti- $\beta$ APP antibody (A8717), monoclonal anti- $\beta$ actin (A2228), dimethyl sulfoxide (DMSO), SDS, and sodium bicarbonate were from Sigma (St. Louis, MO, USA). Polyclonal anti-ADAM10 (AB19026) was from Millipore (Bedford, MA, USA). Monoclonal anti-BACE1 (ab108394) was from Abcam (Cambridge, UK). Skim milk powder was from Bio Basic (Singapore). Monoclonal anti- $\beta$-amyloid antibody (2B3), which was used to specifically detect SAPP $\alpha$ was from IBL (Minneapolis, MN, USA). ECL reagent and ammonium persulphate were from GE Health care (Pisataway, NJ, USA). OPhenanthroline was from Calbiochem (San Diego, CA, USA). Goat anti-mouse (polyclonal 7076) and goat anti-rabbit (polyclonal 7074) peroxidase-conjugated secondary antibodies were from Cell Signaling (Beverly, MA, USA).

\subsection{General Information for Chemistry}

${ }^{1} \mathrm{H}$ and ${ }^{13} \mathrm{C}$ NMR spectra (Supplementary Materials) were recorded on a Bruker AV400 spectrometer at 400 and $100 \mathrm{MHz}$, respectively, in $\mathrm{CDCl}_{3}, \mathrm{CD}_{3} \mathrm{OD},\left(\mathrm{CD}_{3}\right)_{2} \mathrm{SO}$, and $\mathrm{C}_{6} \mathrm{D}_{6}$ as indicated. Coupling constants $(J)$ are expressed in hertz $(\mathrm{Hz})$. Chemical shifts $(\delta)$ of NMR are reported in parts per million (ppm) units relative to the solvent. The high resolution of ESI-MS was recorded on an Applied Biosystems Q-STAR Elite ESI-LC-MS/MS mass spectrometer, respectively. Unless otherwise noted, materials were obtained from commercial suppliers and used without further purification. Melting points were measured using an YRT-3 melting point apparatus (Shanghai Yice Apparatus \& Equipment Co., Ltd., Shanghai, China) and were uncorrected.

\subsection{Synthesis of Andrographolide Derivatives}

\subsubsection{Synthesis of Compounds $\mathbf{7}$ to $\mathbf{1 0}$ and $\mathbf{1 2}$ to $\mathbf{1 6}$}

The synthesis of compounds $\mathbf{7}$ to $\mathbf{1 0}$ and $\mathbf{1 2}$ to $\mathbf{1 6}$ (Scheme 1) was previously described [32,33]. 


\subsubsection{Synthesis of Compounds $\mathbf{1 1}, \mathbf{1 7}$, and $\mathbf{1 8}$}

The synthesis of compounds 11, 17, and 18 (Scheme 1) was conducted according to previously described procedures [32-34].

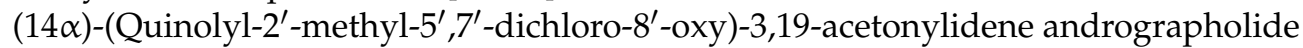
(11): white solid; m.p. $166.3-167.0{ }^{\circ} \mathrm{C} ; 72.6 \%$ yield; ${ }^{1} \mathrm{H}$ NMR $\left(400 \mathrm{MHz}\right.$, DMSO- $\left.d_{6}\right) \delta 8.48(\mathrm{~d}$, $J=8.7 \mathrm{~Hz}, 1 \mathrm{H}), 7.92(\mathrm{~s}, 1 \mathrm{H}), 7.69(\mathrm{~d}, J=8.7 \mathrm{~Hz}, 1 \mathrm{H}), 6.74-6.65(\mathrm{~m}, 1 \mathrm{H}), 6.37(\mathrm{~d}, J=4.6 \mathrm{~Hz}$, $1 \mathrm{H}), 4.75-4.68(\mathrm{~m}, 2 \mathrm{H}), 4.60(\mathrm{~m}, 1 \mathrm{H}), 4.10(\mathrm{~s}, 1 \mathrm{H}), 3.76(\mathrm{~d}, J=11.6 \mathrm{~Hz}, 1 \mathrm{H}), 3.31-3.26(\mathrm{~m}, 1 \mathrm{H})$, $3.03(\mathrm{~d}, J=11.6 \mathrm{~Hz}, 1 \mathrm{H}), 2.77(\mathrm{~s}, 3 \mathrm{H}), 2.23(\mathrm{~d}, J=12.2 \mathrm{~Hz}, 1 \mathrm{H}), 1.90-1.69(\mathrm{~m}, 3 \mathrm{H}), 1.63(\mathrm{~d}$, $J=11.6 \mathrm{~Hz}, 1 \mathrm{H}), 1.55(\mathrm{~m}, 3 \mathrm{H}), 1.31(\mathrm{~s}, 3 \mathrm{H}), 1.24(\mathrm{~s}, 3 \mathrm{H}), 1.09(\mathrm{~d}, J=4.4 \mathrm{~Hz}, 2 \mathrm{H}), 1.06(\mathrm{~s}, 3 \mathrm{H})$, $0.92(\mathrm{~m}, 2 \mathrm{H}), 0.46(\mathrm{~s}, 3 \mathrm{H}) ;{ }^{13} \mathrm{C}$ NMR $(101 \mathrm{MHz}, \mathrm{DMSO}) \delta 170.0,160.9,148.7,147.7,147.2$, $142.9,133.8,127.4,126.9,126.6,124.7,124.5,108.3,98.6,77.0,76.2,72.3,63.1,54.8,51.8,38.2$, $37.5,37.3,34.2,28.0,26.2,25.8,25.5,25.2,25.1,23.0,15.6$; HRMS (ESI) $m / z 600.2280[\mathrm{M}+$ $\mathrm{H}]^{+}$, calculated for $\mathrm{C}_{33} \mathrm{H}_{40} \mathrm{Cl}_{2} \mathrm{NO}_{5}, 600.2284$.

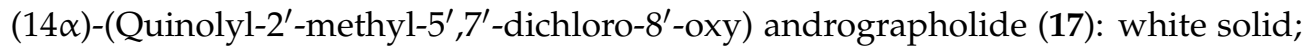
m.p. $142.0-142.4{ }^{\circ} \mathrm{C}$; $75.1 \%$ yield; ${ }^{1} \mathrm{H}$ NMR $\left(400 \mathrm{MHz}\right.$, DMSO- $\left.d_{6}\right) \delta 8.48(\mathrm{~d}, J=8.7 \mathrm{~Hz}$, $1 \mathrm{H}), 7.91(\mathrm{~s}, 1 \mathrm{H}), 7.75-7.61(\mathrm{~m}, 1 \mathrm{H}), 6.68(\mathrm{dd}, J=8.7,5.0 \mathrm{~Hz}, 1 \mathrm{H}), 6.35(\mathrm{~d}, J=4.6 \mathrm{~Hz}, 1 \mathrm{H})$, $5.09-4.92(\mathrm{~m}, 1 \mathrm{H}), 4.74-4.65(\mathrm{~m}, 2 \mathrm{H}), 4.60(\mathrm{~m}, 1 \mathrm{H}),, 4.07(\mathrm{~d}, J=19.2 \mathrm{~Hz}, 2 \mathrm{H}), 3.70(\mathrm{~d}, J=10.9$ $\mathrm{Hz}, 1 \mathrm{H}), 3.16(\mathrm{~d}, J=10.8 \mathrm{~Hz}, 1 \mathrm{H}), 3.07(\mathrm{~m}, 1 \mathrm{H}), 2.76(\mathrm{~s}, 3 \mathrm{H}), 2.24-2.14(\mathrm{~m}, 1 \mathrm{H}), 1.77(\mathrm{~m}, 2 \mathrm{H})$, $1.59(\mathrm{~m}, 2 \mathrm{H}), 1.45-1.40(\mathrm{~m}, 2 \mathrm{H}), 1.26-1.13(\mathrm{~m}, 2 \mathrm{H}), 0.99(\mathrm{~m}, 4 \mathrm{H}), 0.80(\mathrm{~m}, 2 \mathrm{H}), 0.22(\mathrm{~s}, 3 \mathrm{H})$; ${ }^{13} \mathrm{C}$ NMR $\left(101 \mathrm{MHz}\right.$, DMSO- $\left.d_{6}\right) \delta 169.6,160.5,148.2,147.3,146.8,142.5,133.5,127.0,126.5$, 126.2, 126.1, 124.2, 124.1, 107.4, 78.2, 76.6, 71.9, 62.5, 54.4, 54.1, 42.2, 38.3, 37.2, 36.0, 27.7, 25.1, 24.4, 23.9, 23.0, 14.1; HRMS (ESI) $m / z 560.1972[\mathrm{M}+\mathrm{H}]^{+}$, calculated for $\mathrm{C}_{30} \mathrm{H}_{36} \mathrm{Cl}_{2} \mathrm{NO}_{5}$, 560.1971.

(14ß)-(Quinolyl-2'-methyl-5', $7^{\prime}$-dichloro-8'-oxy) andrographolide (18): white solid; m.p. $172.1-172.7^{\circ} \mathrm{C} ; 74.4 \%$ yield; ${ }^{1} \mathrm{H}$ MR $\left(400 \mathrm{MHz}, \mathrm{DMSO}-d_{6}\right) \delta 8.46(\mathrm{~d}, J=8.7 \mathrm{~Hz}, 1 \mathrm{H})$, $7.90(\mathrm{~s}, 1 \mathrm{H}), 7.68(\mathrm{~d}, J=8.8 \mathrm{~Hz}, 1 \mathrm{H}), 6.59(\mathrm{~m}, J=8.5,4.6 \mathrm{~Hz}, 1 \mathrm{H}), 6.48(\mathrm{~d}, J=4.5 \mathrm{~Hz}, 1 \mathrm{H}), 5.00$ $(\mathrm{d}, J=4.8 \mathrm{~Hz}, 1 \mathrm{H}), 4.72-4.64(\mathrm{~m}, 2 \mathrm{H}), 4.60(\mathrm{~m}, J=11.0,4.7 \mathrm{~Hz}, 1 \mathrm{H}), 4.13(\mathrm{~s}, 1 \mathrm{H}), 4.07-4.04$ $(\mathrm{m}, 1 \mathrm{H}), 3.71(\mathrm{~m}, J=10.9,2.9 \mathrm{~Hz}, 1 \mathrm{H}), 3.15(\mathrm{~m}, 1 \mathrm{H}), 3.09(\mathrm{~m}, 1 \mathrm{H}), 2.75(\mathrm{~s}, 3 \mathrm{H}), 2.23-2.13(\mathrm{~m}$, $1 \mathrm{H}), 1.83-1.68(\mathrm{~m}, 2 \mathrm{H}), 1.59(\mathrm{~d}, J=12.3 \mathrm{~Hz}, 2 \mathrm{H}), 1.45(\mathrm{q}, J=6.6 \mathrm{~Hz}, 2 \mathrm{H}), 1.36-1.20(\mathrm{~m}, 2 \mathrm{H})$, 1.05-0.92 (m, 4H, 1-H), 0.84-0.75 (m, 1H), $0.68(\mathrm{~m}, 1 \mathrm{H}), 0.19(\mathrm{~s}, 3 \mathrm{H}) ;{ }^{13} \mathrm{C}$ NMR $(101 \mathrm{MHz}$, DMSO- $\left.d_{6}\right) \delta 169.5,160.5,149.2,147.6,146.7,142.6,133.3,127.2,126.5,126.3,125.9,124.2$, 124.1, 107.8, 78.2, 76.7, 71.8, 62.5, 54.4, 54.0, 42.1, 38.1, 37.2, 35.9, 27.8, 25.1, 25.0, 23.9, 23.0, 14.3; HRMS (ESI) $m / z 560.1965[\mathrm{M}+\mathrm{H}]^{+}$, calculated for $\mathrm{C}_{30} \mathrm{H}_{36} \mathrm{Cl}_{2} \mathrm{NO}_{5}, 560.1971$.

\subsubsection{Synthesis of Compounds $\mathbf{1 9}$ to $\mathbf{2 6}$}

The key intermediates $\mathbf{2 5}$ and $\mathbf{2 6}$ of the 9-dehydro-17-hydro series were synthesized as shown in Scheme 2.

Synthesis of compound 19: a solution of compound $2(5.0 \mathrm{~g}, 12.8 \mathrm{mmol})$ in $10 \mathrm{~mL}$ of dry dichloromethane $(50 \mathrm{~mL})$ was cooled in ice-water bath and then triethylamine $(4.5 \mathrm{~mL}, 32.0 \mathrm{mmol})$ was added, followed by $p$-nitrobenzoyl chloride $(2.85 \mathrm{~g}, 15.4 \mathrm{mmol})$ in $20 \mathrm{~mL}$ of dry dichloromethane. The reaction mixture was stirred in an ice-water bath for $5 \mathrm{~h}$ and volatile solvents were removed by Rotavapor. The residue was dissolved in ethyl acetate and treated with sat. $\mathrm{NaHCO}_{3}$ aqueous solution. The organic phase was washed with brine twice and then dried over anhydrous $\mathrm{Na}_{2} \mathrm{SO}_{4}$. The filtered organic solution was evaporated to dryness and the residue was purified by silica gel column chromatography (petroleum ether/ethyl acetate 3/1) to afford $5.9 \mathrm{~g}$ of titled compound 19. (14 $\alpha)$-(4'-nitrobenzoyl)-3,19-isopropylideneoxy andrographolide (19): white solid; m.p. 82.7-84.1 ${ }^{\circ} \mathrm{C} ; 86.9 \%$ yield; ${ }^{1} \mathrm{H}$ NMR (400 MHz, Chloroform- $d$ ) $\delta 8.37-8.28(\mathrm{~m}, 2 \mathrm{H}), 8.25-8.14$ $(\mathrm{m}, 2 \mathrm{H}), 7.14(\mathrm{~m}, 1 \mathrm{H}), 6.24(\mathrm{~d}, J=5.9 \mathrm{~Hz}, 1 \mathrm{H}), 4.85(\mathrm{~s}, 1 \mathrm{H}), 4.68(\mathrm{~m}, 1 \mathrm{H}), 4.50(\mathrm{~s}, 1 \mathrm{H}), 4.41$ $(\mathrm{m}, 1 \mathrm{H}), 3.91(\mathrm{~d}, J=11.5 \mathrm{~Hz}, 1 \mathrm{H}), 3.48(\mathrm{~m}, 1 \mathrm{H}), 3.15(\mathrm{~d}, J=11.6 \mathrm{~Hz}, 1 \mathrm{H}), 2.54-2.47(\mathrm{~m}, 1 \mathrm{H})$, 2.43-2.36 (m, 1H), 2.02-1.92 (m, 2H), $1.89(\mathrm{~d}, J=10.0 \mathrm{~Hz}, 1 \mathrm{H}), 1.81-1.74(\mathrm{~m}, 1 \mathrm{H}), 1.69(\mathrm{~m}$, $2 \mathrm{H}), 1.37(\mathrm{~s}, 3 \mathrm{H}), 1.35(\mathrm{~s}, 3 \mathrm{H}), 1.30(\mathrm{t}, J=6.4 \mathrm{~Hz}, 1 \mathrm{H}), 1.26(\mathrm{~d}, J=3.7 \mathrm{~Hz}, 2 \mathrm{H}), 1.18(\mathrm{~s}, 3 \mathrm{H})$, $0.87(\mathrm{~s}, 3 \mathrm{H}), 0.86-0.85(\mathrm{~m}, 1 \mathrm{H})$. 
Synthesis of compound 20: to a solution of compound $2(5.0 \mathrm{~g}, 12.8 \mathrm{mmol}), p$ nitrobenzoic acid $(2.57 \mathrm{~g}, 15.4 \mathrm{mmol})$ and triphenylphosphine $(5.0 \mathrm{~g}, 19.2 \mathrm{mmol})$ in anhydrous THF $\left(50 \mathrm{~mL}\right.$ ) placed under $\mathrm{N}_{2}$ and at $0{ }^{\circ} \mathrm{C}$, diisopropyl azodicarboxylate (DIAD) $\left(3.76 \mathrm{~mL}, 19.2 \mathrm{mmol}\right.$ ) was added. The reaction was stirred at $0{ }^{\circ} \mathrm{C}$ for $1 \mathrm{~h}$ and at room temperature overnight. After the reaction was complete as established by TLC monitoring, the volatile solvents were distilled off, the residue was dissolved in ethyl acetate and the organic phase was washed with brine twice, dried over anhydrous $\mathrm{Na}_{2} \mathrm{SO}_{4}$, filtered, and evaporated to dryness. Titled compound 20 was purified by silica gel column chromatography (petroleum ether/ethyl acetate $8 / 1$ ) to yield $5.3 \mathrm{~g}$. (14 $\beta)-\left(4^{\prime}\right.$-nitrobenzoyl)3,19-isopropylideneoxy andrographolide (20): white solid; m.p. $109.6-110.8{ }^{\circ} \mathrm{C} ; 77.5 \%$ yield; ${ }^{1} \mathrm{H}$ NMR $(400 \mathrm{MHz}$, Chloroform- $d) \delta 8.36(\mathrm{~d}, J=8.9 \mathrm{~Hz}, 2 \mathrm{H}), 8.24(\mathrm{~d}, J=8.8 \mathrm{~Hz}, 2 \mathrm{H})$, 7.21-7.15 (m, 1H), $6.29(\mathrm{~d}, J=5.8 \mathrm{~Hz}, 1 \mathrm{H}), 5.00(\mathrm{~m}, 1 \mathrm{H}), 4.93(\mathrm{~s}, 1 \mathrm{H}), 4.71(\mathrm{~m}, 1 \mathrm{H}), 4.49(\mathrm{~s}$, $1 \mathrm{H}), 4.43(\mathrm{~m}, 1 \mathrm{H}), 3.88(\mathrm{~d}, J=11.6 \mathrm{~Hz}, 1 \mathrm{H}), 3.41-3.28(\mathrm{~m}, 1 \mathrm{H}), 3.14(\mathrm{~d}, J=11.6 \mathrm{~Hz}, 1 \mathrm{H})$, 2.54-2.50 (m, 1H), $2.44(\mathrm{~d}, J=13.3 \mathrm{~Hz}, 1 \mathrm{H}), 2.01-1.87(\mathrm{~m}, 2 \mathrm{H}), 1.71(\mathrm{~m}, 2 \mathrm{H}), 1.36(\mathrm{~s}, 3 \mathrm{H}), 1.34$ $(\mathrm{s}, 3 \mathrm{H}), 1.30(\mathrm{~s}, 4 \mathrm{H}), 1.16(\mathrm{~d}, J=2.6 \mathrm{~Hz}, 1 \mathrm{H}), 1.11(\mathrm{~s}, 3 \mathrm{H}), 0.92(\mathrm{~s}, 3 \mathrm{H})$.

Synthesis of compound 21: compound $19(5.9 \mathrm{~g}, 10.9 \mathrm{mmol})$ was added to $85 \%$ phosphoric acid $(40.0 \mathrm{mmol})$ with fast stirring and the solid was dissolved gradually. The reaction was monitored by TLC and complete in about $3 \mathrm{~h}$ before being diluted carefully with distilled water followed by extraction with ethyl acetate. The organic phase was washed with a sat. $\mathrm{NaHCO}_{3}$ aqueous solution and brine and then dried over anhydrous $\mathrm{Na}_{2} \mathrm{SO}_{4}$. Filtered organic phase was evaporated and the residue was purified by silica gel column chromatography (petroleum ether/ethyl acetate $3 / 1$ ) to yield $3.6 \mathrm{~g}$ of compound 21. (14 $\alpha)$-( $4^{\prime}$-nitrobenzoyl)-9-dehydro-17-hydro andrographolide (21): white solid; m.p. 97.3-98.5 ${ }^{\circ} \mathrm{C} ; 66.7 \%$ yield; ${ }^{1} \mathrm{H}$ NMR (400 MHz, Chloroform- $d$ ) $\delta 8.39-8.27(\mathrm{~m}, 2 \mathrm{H}), 8.23-8.14$ $(\mathrm{m}, 2 \mathrm{H}), 6.99(\mathrm{~m}, 1 \mathrm{H}), 6.26(\mathrm{~d}, J=5.8 \mathrm{~Hz}, 1 \mathrm{H}), 4.68(\mathrm{~m}, 1 \mathrm{H}), 4.42(\mathrm{~m}, 1 \mathrm{H}), 4.17(\mathrm{~d}, J=11.2 \mathrm{~Hz}$, $1 \mathrm{H}), 3.40(\mathrm{~d}, J=8.8 \mathrm{~Hz}, 1 \mathrm{H}), 3.30(\mathrm{~s}, 1 \mathrm{H}), 3.08(\mathrm{~m}, 1 \mathrm{H}), 2.95(\mathrm{~m}, 1 \mathrm{H}), 2.73(\mathrm{~d}, J=8.5 \mathrm{~Hz}, 1 \mathrm{H})$, $2.53(\mathrm{~s}, 1 \mathrm{H}), 2.03(\mathrm{~m}, 2 \mathrm{H}), 1.82-1.64(\mathrm{~m}, 4 \mathrm{H}), 1.50(\mathrm{~s}, 3 \mathrm{H}), 1.40-1.27(\mathrm{~m}, 2 \mathrm{H}), 1.23(\mathrm{~s}, 3 \mathrm{H})$, $1.20-1.16(\mathrm{~m}, 1 \mathrm{H}), 0.89(\mathrm{~s}, 3 \mathrm{H}) .{ }^{13} \mathrm{C}$ NMR $\left(101 \mathrm{MHz}, \mathrm{DMSO}-d_{6}\right) \delta 169.4,164.3,150.9,150.2$, 136.7, 134.9, 131.4 (2C), 129.1, 124.4 (2C), 123.9, 78.6, 71.6, 69.8, 63.2, 51.7, 42.6, 38.6, 34.9, 34.4, 28.5, 28.0, 23.3, 20.5, 19.7, 19.4. HRMS (ESI) $\mathrm{m} / z$ 522.2101 [M + Na] ${ }^{+}$, calculated for $\mathrm{C}_{27} \mathrm{H}_{33} \mathrm{NO}_{8} \mathrm{Na}, 522.2098$.

Synthesis of compound 22: compound 22 was synthetized from compound 20 fol-

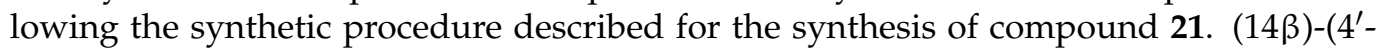
nitrobenzoyl)-9-dehydro-17-hydro andrographolide (22): white solid; m.p. $107.8-109.1^{\circ} \mathrm{C}$; $68.5 \%$ yield; ${ }^{1} \mathrm{H}$ NMR $(400 \mathrm{MHz}$, Chloroform- $d) \delta 8.33(\mathrm{~d}, J=8.9 \mathrm{~Hz}, 2 \mathrm{H}), 8.20(\mathrm{~d}, J=8.8 \mathrm{~Hz}$, $2 \mathrm{H}), 6.99(\mathrm{t}, J=7.0 \mathrm{~Hz}, 1 \mathrm{H}), 6.27(\mathrm{~d}, J=5.8 \mathrm{~Hz}, 1 \mathrm{H}), 4.68(\mathrm{~m}, 1 \mathrm{H}), 4.42(\mathrm{~m}, 1 \mathrm{H}), 4.15(\mathrm{~d}$, $J=11.2 \mathrm{~Hz}, 1 \mathrm{H}), 3.49-3.39(\mathrm{~m}, 1 \mathrm{H}), 3.30(\mathrm{~d}, J=11.1 \mathrm{~Hz}, 1 \mathrm{H}), 3.09(\mathrm{~m}, 1 \mathrm{H}), 2.96(\mathrm{~m}, 1 \mathrm{H})$, $2.66(\mathrm{~s}, 1 \mathrm{H}), 2.43(\mathrm{~s}, 1 \mathrm{H}), 2.03(\mathrm{~d}, J=8.0 \mathrm{~Hz}, 2 \mathrm{H}), 1.81-1.68(\mathrm{~m}, 4 \mathrm{H}), 1.51(\mathrm{~s}, 3 \mathrm{H}), 1.38-1.32$ $(\mathrm{m}, 1 \mathrm{H}), 1.29(\mathrm{~d}, J=7.6 \mathrm{~Hz}, 1 \mathrm{H}), 1.24(\mathrm{~s}, 3 \mathrm{H}), 0.90-0.86(\mathrm{~m}, 1 \mathrm{H}), 0.85(\mathrm{~s}, 3 \mathrm{H}) .{ }^{13} \mathrm{C}$ NMR (101 MHz, Chloroform-d) $\delta$ 169.1, 164.2, 151.1, 151.0, 135.2, 134.1, 131.0, 130.4, 123.8, 122.8, 80.2, 71.5, 69.3, 64.1, 51.6, 42.7, 38.4, 35.0, 34.2, 28.8, 27.9, 22.5, 20.6, 19.5, 18.7. HRMS (ESI) $\mathrm{m} / z$ 522.2099 $[\mathrm{M}+\mathrm{Na}]^{+}$, calculated for $\mathrm{C}_{27} \mathrm{H}_{33} \mathrm{O}_{8} \mathrm{NNa}, 522.2098$.

Synthesis of compound 23: compound 21 (3.6 g, $7.2 \mathrm{mmol})$ was dissolved in 2,2dimethoxypropane $(7.5 \mathrm{~mL}, 50.4 \mathrm{mmol})$ and $2.5 \mathrm{~mL}$ dry dichloromethane and pyridinium 4-toluenesulfonate $(88 \mathrm{mg}, 0.36 \mathrm{mmol})$ was added. The reaction was stirred at $45^{\circ} \mathrm{C}$ and complete in $3 \mathrm{~h}$ as monitored by TLC. After volatile solvents were distilled off, the residue was taken off with ethyl acetate and the organic phase was washed with sat. $\mathrm{CuSO}_{4}$ aqueous solution, sat. $\mathrm{NaHCO}_{3}$ solution, and brine. The organic phase was dried over anhydrous $\mathrm{Na}_{2} \mathrm{SO}_{4}$, filtered, and evaporated in vacuo, and the residue was purified by silica gel column chromatography (petroleum ether/ethyl acetate $3 / 1$ ) to give $3.1 \mathrm{~g}$ of compound 23. (14 $\alpha)$-(4'-nitrobenzoyl)-9-dehydro-17-hydro-3,19-isopropylideneoxy andrographolide (23): white solid; m.p. $90.3-91.7{ }^{\circ} \mathrm{C} ; 76.9 \%$ yield; ${ }^{1} \mathrm{H}$ NMR (400 MHz, DMSO-d6) $\delta 8.40-8.33$ $(\mathrm{m}, 2 \mathrm{H}), 8.24-8.17(\mathrm{~m}, 2 \mathrm{H}), 6.78-6.72(\mathrm{~m}, 1 \mathrm{H}), 6.32(\mathrm{~d}, J=5.8 \mathrm{~Hz}, 1 \mathrm{H}), 4.72(\mathrm{~m}, 1 \mathrm{H}), 4.56$ $(\mathrm{m}, 1 \mathrm{H}), 3.82(\mathrm{~d}, J=11.6 \mathrm{~Hz}, 1 \mathrm{H}), 3.29(\mathrm{~m}, 1 \mathrm{H}), 3.15-3.00(\mathrm{~m}, 3 \mathrm{H}), 1.97(\mathrm{~d}, J=7.3 \mathrm{~Hz}, 2 \mathrm{H})$, 
1.69-1.61 (m, 1H), $1.55(\mathrm{~s}, 2 \mathrm{H}), 1.50(\mathrm{~s}, 3 \mathrm{H}), 1.45$ (d, J = 5.4 Hz, 1H), 1.37-1.27 (m, 1H), 1.21 $(\mathrm{s}, 6 \mathrm{H}), 1.14(\mathrm{~m}, 2 \mathrm{H}), 1.06(\mathrm{~d}, J=1.8 \mathrm{~Hz}, 6 \mathrm{H})$.

Synthesis of compound 24: the procedure for the synthesis of compound 24 from compound 22 is the same as for the synthesis of compound 23. (14 $\beta)-\left(4^{\prime}\right.$-nitrobenzoyl)-9dehydro-17-hydro-3,19-isopropylideneoxy andrographolide (24): white solid; m.p. 153.7$154.4{ }^{\circ} \mathrm{C} ; 82.1 \%$ yield; ${ }^{1} \mathrm{H}$ NMR $(400 \mathrm{MHz}, \mathrm{DMSO}-d 6) \delta 8.90(\mathrm{~s}, 2 \mathrm{H}), 8.43-8.32(\mathrm{~m}, 2 \mathrm{H})$, 8.27-8.17 (m, 2H), $6.74(\mathrm{t}, J=6.7 \mathrm{~Hz}, 1 \mathrm{H}), 6.33(\mathrm{~d}, J=5.9 \mathrm{~Hz}, 1 \mathrm{H}), 4.80-4.70(\mathrm{~m}, 3 \mathrm{H}), 4.57$ $(\mathrm{m}, 1 \mathrm{H}), 3.83(\mathrm{~d}, J=11.6 \mathrm{~Hz}, 1 \mathrm{H}), 3.11(\mathrm{~d}, J=10.9 \mathrm{~Hz}, 1 \mathrm{H}), 1.50(\mathrm{~s}, 3 \mathrm{H}), 1.40(\mathrm{~s}, 2 \mathrm{H}), 1.23(\mathrm{~d}$, $J=3.2 \mathrm{~Hz}, 6 \mathrm{H}), 1.19(\mathrm{~s}, 6 \mathrm{H}), 1.09$ (s, 3H), 1.03 (s, 3H).

Synthesis of compound 25 (key intermediate): to a solution of compound 23 (3.1 g, $5.7 \mathrm{mmol}$ ) in $20 \mathrm{~mL}$ methanol, lithium carbonate (794 mg, $11.5 \mathrm{mmol}$ ) was added, and the mixture was stirred at room temperature for $2 \mathrm{~h}$ (TLC monitoring). After removal of volatile solvents by rotavapor, the residue was treated with ethyl acetate and the organic phase was washed with brine twice, dried over anhydrous $\mathrm{Na}_{2} \mathrm{SO}_{4}$, filtered, and distilled off to dryness. The residue was purified by silica gel column chromatography (petroleum ether/ethyl acetate 3/1) to give $1.6 \mathrm{~g}$ of titled compound 25 . (14 $\alpha$ )-9-dehydro-17-hydro3,19-isopropylideneoxy andrographolide (25): white solid; m.p. $138.2-139.4{ }^{\circ} \mathrm{C} ; 71.4 \%$ yield; ${ }^{1} \mathrm{H}$ NMR $(400 \mathrm{MHz}$, Chloroform- $d) \delta 6.88(\mathrm{~m}, 1 \mathrm{H}), 5.07(\mathrm{~s}, 1 \mathrm{H}), 4.53-4.44(\mathrm{~m}, 1 \mathrm{H})$, $4.26(\mathrm{~m}, 1 \mathrm{H}), 3.99(\mathrm{~d}, J=11.6 \mathrm{~Hz}, 1 \mathrm{H}), 3.48(\mathrm{~m}, 1 \mathrm{H}), 3.26-3.14(\mathrm{~m}, 2 \mathrm{H}), 3.04(\mathrm{~m}, 1 \mathrm{H}), 2.04(\mathrm{~m}$, 2H), 1.99-1.92 (m, 1H), 1.78-1.69 (m, 2H), 1.68-1.61 (m, 2H), $1.55(\mathrm{~s}, 3 \mathrm{H}), 1.50-1.43(\mathrm{~m}, 1 \mathrm{H})$, $1.41(\mathrm{~s}, 3 \mathrm{H}), 1.37(\mathrm{~s}, 3 \mathrm{H}), 1.32(\mathrm{~d}, J=6.2 \mathrm{~Hz}, 1 \mathrm{H}), 1.28(\mathrm{~d}, J=1.9 \mathrm{~Hz}, 1 \mathrm{H}), 1.25(\mathrm{~d}, J=2.1 \mathrm{~Hz}$, $3 \mathrm{H}), 1.17$ (s, 3H). ${ }^{13} \mathrm{C}$ NMR $\left(101 \mathrm{MHz}, \mathrm{DMSO}-d_{6}\right) \delta 170.4,146.2,137.6,128.9,128.1,98.8$, 75.7, 74.7, 65.2, 63.4, 48.6, 37.8, 37.6, 33.6, 32.2, 28.2, 27.3, 26.1, 25.8, 24.9, 22.2, 19.7, 18.32. HRMS (ESI) $m / z 413.2299[\mathrm{M}+\mathrm{Na}]^{+}$,calculated for $\mathrm{C}_{23} \mathrm{H}_{34} \mathrm{O}_{5} \mathrm{Na}, 413.2298$.

Synthesis of compound 26 (key intermediate): the synthetic procedure for compound 26 from compound $\mathbf{2 4}$ is the same as that for compound 25. (14 $\beta$ )-9-dehydro-17-hydro3,19-isopropylideneoxy andrographolide (26): white solid; m.p. 93.2-94.7 ${ }^{\circ} \mathrm{C} ; 72.6 \%$ yield; ${ }^{1} \mathrm{H}$ NMR $(400 \mathrm{MHz}$, Chloroform- $d) \delta 6.88(\mathrm{t}, J=6.1 \mathrm{~Hz}, 1 \mathrm{H}), 5.10(\mathrm{t}, J=6.5 \mathrm{~Hz}, 1 \mathrm{H}), 4.48(\mathrm{~m}$, $1 \mathrm{H}), 4.27(\mathrm{~m}, 1 \mathrm{H}), 3.99(\mathrm{~d}, J=11.6 \mathrm{~Hz}, 1 \mathrm{H}), 3.50(\mathrm{~m}, 1 \mathrm{H}), 3.21(\mathrm{~d}, J=11.6 \mathrm{~Hz}, 1 \mathrm{H}), 3.12(\mathrm{~d}$, $J=7.0 \mathrm{~Hz}, 2 \mathrm{H}), 2.07-1.96(\mathrm{~m}, 3 \mathrm{H}), 1.93(\mathrm{~d}, J=6.7 \mathrm{~Hz}, 1 \mathrm{H}), 1.81-1.72(\mathrm{~m}, 2 \mathrm{H}), 1.64(\mathrm{~m}, 1 \mathrm{H})$, $1.52(\mathrm{~s}, 3 \mathrm{H}), 1.43(\mathrm{~s}, 1 \mathrm{H}), 1.41(\mathrm{~s}, 3 \mathrm{H}), 1.37(\mathrm{~s}, 3 \mathrm{H}), 1.30(\mathrm{~d}, J=1.8 \mathrm{~Hz}, 1 \mathrm{H}), 1.28(\mathrm{~d}, J=5.8 \mathrm{~Hz}$, $1 \mathrm{H}), 1.21(\mathrm{~s}, 3 \mathrm{H}), 1.19(\mathrm{~s}, 3 \mathrm{H}) .{ }^{13} \mathrm{C}$ NMR (101 MHz, DMSO-d6) $\delta 170.4,146.0,137.6,129.0$, $128.3,98.8,75.9,74.7,65.2,63.3,48.8,37.9,37.5,33.7,32.6,28.2,27.5,26.1,25.9,25.1,22.1$, 19.6, 18.3. HRMS (ESI) $m / z$ 413.2297 [M + Na] ${ }^{+}$, calculated for $\mathrm{C}_{23} \mathrm{H}_{34} \mathrm{O}_{5} \mathrm{Na}, 413.2298$.

\subsubsection{Synthesis of Compounds 27 to 32}

Titled 9-dehydro-17-hydro series compounds 27 to 32 were prepared as shown in Scheme 2 according to previously described procedures [32-34]. Under $\mathrm{N}_{2}$ atmosphere, $1.0 \mathrm{mmol}$ of compound 25 or $26,1.5 \mathrm{mmol}$ of $\mathrm{PPh}_{3}$, and $1.5 \mathrm{mmol}$ of 8-hydroxyquinoline derivative 4, 5, or 6 were dissolved in $10.0 \mathrm{~mL}$ of anhydrous THF. The solution was cooled to $0{ }^{\circ} \mathrm{C}$ and then treated with $1.5 \mathrm{mmol}$ of DIAD in $2.0 \mathrm{~mL}$ of anhydrous THF. The reaction was stirred overnight at room temperature after being stirred at $0{ }^{\circ} \mathrm{C}$ for $1 \mathrm{~h}$. After distilling off the volatile solvents, the residue was dissolved in ethyl acetate and the organic phase was washed with brine about 5 times and dried over anhydrous $\mathrm{Na}_{2} \mathrm{SO}_{4}$. The filtered organic solution was evaporated to dryness and the residue was purified by silica gel column chromatography to afford compounds 27 to 32.

$(14 \alpha)$-(2'-Methyl-8' -quinolinoxy)-9-dehydro-17-hydro-3,19-isopropylideneoxy-andrographolide (27): white solid; m.p. $87.2-87.7^{\circ} \mathrm{C} ; 69.5 \%$ yield; ${ }^{1} \mathrm{H}$ NMR (400 MHz, Chloroform- $d$ ) $\delta 8.08(\mathrm{~d}, J=8.5 \mathrm{~Hz}, 1 \mathrm{H}), 7.55(\mathrm{~d}, J=7.7 \mathrm{~Hz}, 1 \mathrm{H}), 7.42(\mathrm{t}, J=7.8 \mathrm{~Hz}, 1 \mathrm{H}), 7.35(\mathrm{~d}, J=8.4 \mathrm{~Hz}$, 1H), 7.16-7.13 (m, 1H), $7.00(\mathrm{~s}, 1 \mathrm{H}), 6.17(\mathrm{~d}, J=5.6 \mathrm{~Hz}, 1 \mathrm{H}), 4.77(\mathrm{~m}, 1 \mathrm{H}), 4.66(\mathrm{~m}, 1 \mathrm{H}), 3.96$ $(\mathrm{d}, J=11.5 \mathrm{~Hz}, 1 \mathrm{H}), 3.46(\mathrm{~m}, 1 \mathrm{H}), 3.19(\mathrm{~d}, J=11.6 \mathrm{~Hz}, 1 \mathrm{H}), 2.98(\mathrm{~d}, J=17.1 \mathrm{~Hz}, 1 \mathrm{H}), 2.78$ (s, 3H), 2.09 (d, J = 45.1 Hz, 2H), 1.94-1.82 (m, 2H), $1.52(\mathrm{~s}, 3 \mathrm{H}), 1.45(\mathrm{~s}, 6 \mathrm{H}), 1.38(\mathrm{~s}, 3 \mathrm{H})$, $1.26(\mathrm{~s}, 1 \mathrm{H}), 1.21(\mathrm{~d}, J=10.8 \mathrm{~Hz}, 2 \mathrm{H}), 1.16(\mathrm{~s}, 3 \mathrm{H}), 1.12(\mathrm{~d}, J=6.2 \mathrm{~Hz}, 3 \mathrm{H})$. HRMS (ESI) $m / z$ 532.3057 $[\mathrm{M}+\mathrm{H}]^{+}$, calculated for $\mathrm{C}_{33} \mathrm{H}_{42} \mathrm{NO}_{5}, 532.3057$. 
(14ß)-(2'-Methyl-8' -quinolinoxy)-9-dehydro-17-hydro-3,19-isopropylideneoxy-andrographolide (28): white solid; m.p. 99.6-100.3 ${ }^{\circ} \mathrm{C}$; $76.2 \%$ yield; ${ }^{1} \mathrm{H}$ NMR $(400 \mathrm{MHz}$, Chloroformd) $\delta 8.06(\mathrm{~d}, J=8.4 \mathrm{~Hz}, 1 \mathrm{H}), 7.53(\mathrm{~m}, 1 \mathrm{H}), 7.39(\mathrm{t}, J=7.9 \mathrm{~Hz}, 1 \mathrm{H}), 7.32(\mathrm{~d}, J=8.4 \mathrm{~Hz}, 1 \mathrm{H})$, $7.13(\mathrm{~m}, 1 \mathrm{H}), 6.97(\mathrm{~m}, 1 \mathrm{H}), 6.14(\mathrm{~d}, J=5.8 \mathrm{~Hz}, 1 \mathrm{H}), 4.92(\mathrm{~d}, J=6.8 \mathrm{~Hz}, 1 \mathrm{H}), 4.74(\mathrm{~m}, 1 \mathrm{H}), 4.62$ $(\mathrm{m}, 1 \mathrm{H}), 3.95(\mathrm{~d}, J=11.6 \mathrm{~Hz}, 1 \mathrm{H}), 3.46(\mathrm{~m}, 1 \mathrm{H}), 3.18(\mathrm{~d}, J=11.5 \mathrm{~Hz}, 1 \mathrm{H}), 2.89(\mathrm{~d}, J=6.8 \mathrm{~Hz}$, 2H), 2.75 (s, 3H), $1.96(\mathrm{~m}, 3 \mathrm{H}), 1.76-1.67(\mathrm{~m}, 1 \mathrm{H}), 1.45(\mathrm{~s}, 3 \mathrm{H}), 1.39(\mathrm{~s}, 3 \mathrm{H}), 1.37(\mathrm{~s}, 1 \mathrm{H}), 1.36$ $(\mathrm{s}, 3 \mathrm{H}), 1.21(\mathrm{~m}, 3 \mathrm{H}), 1.16(\mathrm{~s}, 3 \mathrm{H}), 1.05(\mathrm{~s}, 3 \mathrm{H}) .{ }^{13} \mathrm{C}$ NMR (101 MHz, Chloroform- $\left.d\right) \delta 170.2$, 158.3, 152.0, 151.0, 141.2, 136.7, 136.4, 128.8, 128.2, 125.6, 124.9, 123.0, 122.6, 118.0, 99.2, 76.0, 74.9, 71.7, 63.9, 48.5, 37.7, 37.6, 33.6, 32.2, 28.9, 26.8, 25.9, 25.6, 25.5, 24.8, 22.1, 19.5, 18.3. HRMS (ESI) $m / z 532.3060[\mathrm{M}+\mathrm{H}]^{+}$, calculated for $\mathrm{C}_{33} \mathrm{H}_{42} \mathrm{NO}_{5}, 532.3057$.

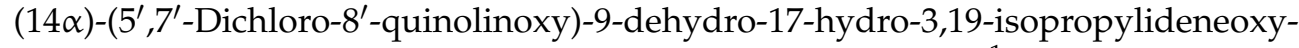
andrographolide (29): white solid; m.p. 86.0-86.5 ${ }^{\circ} \mathrm{C} ; 76.5 \%$ yield; ${ }^{1} \mathrm{H}$ NMR $(400 \mathrm{MHz}$, Chloroform-d) $\delta 9.00(\mathrm{~m}, 1 \mathrm{H}), 8.57(\mathrm{~m}, 1 \mathrm{H}), 7.69(\mathrm{~s}, 1 \mathrm{H}), 7.58(\mathrm{~m}, 1 \mathrm{H}), 6.94-6.83(\mathrm{~m}, 1 \mathrm{H})$, $6.43(\mathrm{~d}, J=5.2 \mathrm{~Hz}, 1 \mathrm{H}), 4.78(\mathrm{~d}, J=11.0 \mathrm{~Hz}, 1 \mathrm{H}), 4.46(\mathrm{~m}, 1 \mathrm{H}), 3.93(\mathrm{~d}, J=11.6 \mathrm{~Hz}, 1 \mathrm{H})$, $3.43(\mathrm{~m}, 1 \mathrm{H}), 3.17(\mathrm{~d}, J=11.6 \mathrm{~Hz}, 1 \mathrm{H}), 2.76(\mathrm{~m}, 1 \mathrm{H}), 2.52(\mathrm{~m}, 1 \mathrm{H}), 1.93(\mathrm{~d}, J=5.4 \mathrm{~Hz}, 1 \mathrm{H})$, 1.92-1.84 (m, 1H), 1.75-1.66 (m, 1H), $1.49(\mathrm{~m}, 2 \mathrm{H}), 1.42(\mathrm{~s}, 1 \mathrm{H}), 1.40(\mathrm{~d}, J=3.2 \mathrm{~Hz}, 6 \mathrm{H}), 1.36$ $(\mathrm{s}, 3 \mathrm{H}), 1.17(\mathrm{~d}, J=5.0 \mathrm{~Hz}, 1 \mathrm{H}), 1.13(\mathrm{~s}, 3 \mathrm{H}), 1.10(\mathrm{~s}, 3 \mathrm{H}), 1.08-1.02(\mathrm{~m}, 1 \mathrm{H}), 0.95(\mathrm{~m}, 1 \mathrm{H})$. ${ }^{13} \mathrm{C}$ NMR (101 MHz, Chloroform-d) $\delta$ 170.3, 151.0, 150.7, 147.5, 143.4, 136.4, 133.8, 128.7, $128.0,127.9,127.0,126.4,124.8,122.3,99.4,76.9,75.5,71.8,64.0,48.1,37.8,37.6,33.6,31.7$, $29.1,26.4,25.8,25.4,24.5,22.3,19.4,18.3$. HRMS (ESI) $m / z 586.2122[\mathrm{M}+\mathrm{H}]^{+}$, calculated for $\mathrm{C}_{32} \mathrm{H}_{38} \mathrm{O}_{5} \mathrm{NCl}_{2}, 586.2122$.

(14ß)-(5',7'-Dichloro-8' -quinolinoxy)-9-dehydro-17-hydro-3,19-isopropylideneoxyandrographolide (30): white solid; m.p. $167.1-167.4{ }^{\circ} \mathrm{C} ; 74.2 \%$ yield; ${ }^{1} \mathrm{H}$ NMR $(400 \mathrm{MHz}$, Chloroform-d) $\delta 8.98(\mathrm{~m}, 1 \mathrm{H}), 8.57(\mathrm{~m}, 1 \mathrm{H}), 7.69(\mathrm{~s}, 1 \mathrm{H}), 7.58(\mathrm{~m}, 1 \mathrm{H}), 6.87(\mathrm{~m}, 1 \mathrm{H}), 6.44(\mathrm{~d}$, $J=5.0 \mathrm{~Hz}, 1 \mathrm{H}), 4.79(\mathrm{~d}, J=11.0 \mathrm{~Hz}, 1 \mathrm{H}), 4.48(\mathrm{~m}, 1 \mathrm{H}), 3.93(\mathrm{~d}, J=11.6 \mathrm{~Hz}, 1 \mathrm{H}), 3.72(\mathrm{~m}, 1 \mathrm{H})$, $3.45(\mathrm{~m}, 1 \mathrm{H}), 3.17(\mathrm{~d}, J=11.5 \mathrm{~Hz}, 1 \mathrm{H}), 2.77(\mathrm{~m}, 1 \mathrm{H}), 2.49(\mathrm{~m}, 1 \mathrm{H}), 1.96(\mathrm{~m}, 2 \mathrm{H}), 1.93-1.86(\mathrm{~m}$, $1 \mathrm{H}), 1.71(\mathrm{~m}, 1 \mathrm{H}), 1.46(\mathrm{~m}, 1 \mathrm{H}), 1.40(\mathrm{~s}, 3 \mathrm{H}), 1.39(\mathrm{~s}, 3 \mathrm{H}), 1.36(\mathrm{~s}, 3 \mathrm{H}), 1.33-1.28(\mathrm{~m}, 1 \mathrm{H}), 1.20$ (m, 2H), $1.16(\mathrm{~s}, 3 \mathrm{H}), 0.97$ (s, 3H). ${ }^{13} \mathrm{C}$ NMR (101 MHz, Chloroform-d) $\delta 170.3,150.6,150.5$, 147.6, 143.4, 136.3, 133.7, 128.9, 128.0, 127.9, 127.0, 126.3, 124.9, 122.3, 99.2, 76.9, 76.0, 71.9, $63.8,48.5,37.7,37.6,33.632 .3,28.8,26.8,25.9,25.5,24.8,22.0,19.4,18.3$. HRMS (ESI) $\mathrm{m} / z$ $586.2125[\mathrm{M}+\mathrm{H}]^{+}$, calculated for $\mathrm{C}_{32} \mathrm{H}_{38} \mathrm{NO}_{5} \mathrm{Cl}_{2}, 586.2122$.

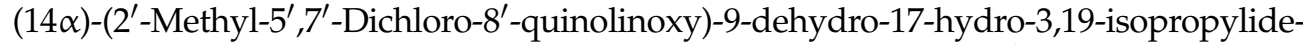
neoxy-andrographolide (31): white solid; m.p. 82.3-82.8 ${ }^{\circ} \mathrm{C} ; 73.4 \%$ yield; ${ }^{1} \mathrm{H}$ NMR (400 MHz, Chloroform- $d) \delta 8.44(\mathrm{~d}, J=8.7 \mathrm{~Hz}, 1 \mathrm{H}), 7.62(\mathrm{~s}, 1 \mathrm{H}), 7.44(\mathrm{~d}, J=8.7 \mathrm{~Hz}, 1 \mathrm{H}), 6.88(\mathrm{~m}, 1 \mathrm{H})$, $6.41(\mathrm{~d}, J=5.0 \mathrm{~Hz}, 1 \mathrm{H}), 4.83(\mathrm{~m}, 1 \mathrm{H}), 4.51(\mathrm{~m}, 1 \mathrm{H}), 3.96(\mathrm{~d}, J=11.6 \mathrm{~Hz}, 1 \mathrm{H}), 3.47(\mathrm{~m}, 1 \mathrm{H})$, $3.20(\mathrm{~d}, J=11.5 \mathrm{~Hz}, 1 \mathrm{H}), 2.85(\mathrm{~m}, 1 \mathrm{H}), 2.80(\mathrm{~s}, 3 \mathrm{H}), 2.63(\mathrm{~m}, 1 \mathrm{H}), 2.06-1.87(\mathrm{~m}, 3 \mathrm{H}), 1.72$ $(\mathrm{m}, 1 \mathrm{H}), 1.48(\mathrm{~m}, 1 \mathrm{H}), 1.42(\mathrm{~s}, 6 \mathrm{H}), 1.38(\mathrm{~s}, 3 \mathrm{H}), 1.36-1.32(\mathrm{~m}, 1 \mathrm{H}), 1.25-1.22(\mathrm{~m}, 1 \mathrm{H}), 1.20$ $(\mathrm{d}, J=1.8 \mathrm{~Hz}, 1 \mathrm{H}), 1.18(\mathrm{~s}, 3 \mathrm{H}), 1.03(\mathrm{~s}, 3 \mathrm{H}), 0.88(\mathrm{~d}, J=3.8 \mathrm{~Hz}, 1 \mathrm{H}) .{ }^{13} \mathrm{C} \mathrm{NMR}(101 \mathrm{MHz}$, Chloroform-d) $\delta 170.3,160.1,150.3,147.1,142.9,136.4,133.7,128.9,127.7,127.0,126.8,125.1$, 124.6, 123.2, 99.2, 76.8, 76.0, 72.0, 63.8, 48.5, 37.7, 37.6, 33.6, 32.2, 28.8, 26.8, 25.9, 25.5, 25.3, 24.8, 22.0, 19.4, 18.3. HRMS (ESI) $m / z$ 600.2281 $[\mathrm{M}+\mathrm{H}]^{+}$, calculated for $\mathrm{C}_{33} \mathrm{H}_{40} \mathrm{NO}_{5} \mathrm{Cl}_{2}$, 600.2278 .

(14ß)-(2'-Methyl-5', $7^{\prime}$-dichloro-8'-quinolinoxy)-9-dehydro-17-hydro-3,19-isopropylideneoxy-andrographolide (32): white solid; m.p. $151.3-152.1^{\circ} \mathrm{C} ; 72.4 \%$ yield; ${ }^{1} \mathrm{H} \mathrm{NMR} \mathrm{(400} \mathrm{MHz,}$ DMSO-d6) $\delta 8.90(\mathrm{~s}, 1 \mathrm{H}), 8.49(\mathrm{~d}, J=8.7 \mathrm{~Hz}, 1 \mathrm{H}), 7.95(\mathrm{~s}, 1 \mathrm{H}), 7.69(\mathrm{~d}, J=8.7 \mathrm{~Hz}, 1 \mathrm{H}), 6.53$ $(\mathrm{m}, 1 \mathrm{H}), 6.46(\mathrm{~d}, J=4.5 \mathrm{~Hz}, 1 \mathrm{H}), 4.77(\mathrm{~m}, 2 \mathrm{H}), 4.67(\mathrm{~d}, J=11.0 \mathrm{~Hz}, 1 \mathrm{H}), 4.58(\mathrm{~m}, 1 \mathrm{H}), 3.83$ $(\mathrm{d}, J=11.6 \mathrm{~Hz}, 1 \mathrm{H}), 3.09(\mathrm{~d}, J=11.5 \mathrm{~Hz}, 1 \mathrm{H}), 2.75(\mathrm{~s}, 3 \mathrm{H}), 1.33(\mathrm{~d}, J=10.3 \mathrm{~Hz}, 6 \mathrm{H}), 1.25$ (s, $3 \mathrm{H}), 1.19$ (d, $J=6.3 \mathrm{~Hz}, 9 \mathrm{H}), 1.08$ (s, 3H), 0.85 (s, 3H). ${ }^{13} \mathrm{C}$ NMR (101 MHz, Chloroform-d) $\delta 170.5,160.2,150.5,147.2,143.0,136.5,133.8,129.0,127.8,127.1,127.0,125.2,124.8,123.3$, 99.3, 76.2, 72.2, 70.2, 63.9, 48.7, 37.8, 37.7, 33.7, 32.4, 29.0, 27.0, 26.1, 25.6, 25.5, 25.0, 22.1, 19.5, 18.4. HRMS (ESI) $m / z 600.2281[\mathrm{M}+\mathrm{H}]^{+}$, calculated for $\mathrm{C}_{33} \mathrm{H}_{40} \mathrm{NO}_{5} \mathrm{Cl}_{2}, 600.2278$. 


\subsubsection{Synthesis of Compounds 33 to 38}

Titled 9-dehydro-17-hydro series compounds 33 to 38 were prepared as shown in Scheme 2 according to references [32-34]. A measure of $0.5 \mathrm{mmol}$ of compounds 27 to 32 was dissolved in $4 \mathrm{~mL}$ of methanol and then treated with $0.05 \mathrm{mmol}$ of $\mathrm{TsOH} \cdot \mathrm{H}_{2} \mathrm{O}$ at $20^{\circ} \mathrm{C}$ for $30 \mathrm{~min}$. The mixture was then diluted with ethyl acetate and washed with sat. aqueous $\mathrm{NaHCO}_{3}$ solution, brine, dried over anhydrous $\mathrm{Na}_{2} \mathrm{SO}_{4}$, filtered, and evaporated by a Rotavapor to dryness. Resulting compounds 33 to 38 were purified by silica gel column chromatography.

(14 $\alpha)$-(2'-Methyl-8'-quinolinoxy)-9-dehydro-17-hydro andrographolide (33): white solid; m.p. $148.3-149.1{ }^{\circ} \mathrm{C} ; 68.5 \%$ yield; ${ }^{1} \mathrm{H}$ NMR $(400 \mathrm{MHz}$, Chloroform- $d) \delta 8.09(\mathrm{~d}$, $J=8.5 \mathrm{~Hz}, 1 \mathrm{H}), 7.55(\mathrm{~m}, 1 \mathrm{H}), 7.42(\mathrm{t}, J=7.8 \mathrm{~Hz}, 1 \mathrm{H}), 7.35(\mathrm{~d}, J=8.4 \mathrm{~Hz}, 1 \mathrm{H}), 7.14(\mathrm{~m}, 1 \mathrm{H})$, $6.96(\mathrm{~m}, 1 \mathrm{H}), 6.21(\mathrm{~d}, J=5.4 \mathrm{~Hz}, 1 \mathrm{H}), 4.97(\mathrm{~s}, 1 \mathrm{H}), 4.74(\mathrm{~m}, 1 \mathrm{H}), 4.64(\mathrm{~m}, 1 \mathrm{H}), 4.20(\mathrm{~m}, 1 \mathrm{H})$, 3.47-3.37 (m, 1H), $3.30(\mathrm{~d}, J=11.6 \mathrm{~Hz}, 1 \mathrm{H}), 3.04(\mathrm{~m}, 1 \mathrm{H}), 2.77(\mathrm{~s}, 3 \mathrm{H}), 2.52(\mathrm{~s}, 1 \mathrm{H}), 2.03(\mathrm{~m}$, $3 \mathrm{H}), 1.75(\mathrm{~s}, 4 \mathrm{H}), 1.56(\mathrm{~s}, 1 \mathrm{H}), 1.55(\mathrm{~s}, 3 \mathrm{H}), 1.23(\mathrm{~s}, 3 \mathrm{H}), 0.94(\mathrm{~s}, 2 \mathrm{H}), 0.80(\mathrm{~s}, 3 \mathrm{H})$. HRMS (ESI) $m / z 492.2746[\mathrm{M}+\mathrm{H}]^{+}$, calculated for $\mathrm{C}_{30} \mathrm{H}_{38} \mathrm{NO}_{5}, 492.2744$.

(14ß)-(2'-Methyl-8'-quinolinoxy)-9-dehydro-17-hydro andrographolide (34): white solid; m.p. $143.3-143.9{ }^{\circ} \mathrm{C}$; $73.2 \%$ yield; ${ }^{1} \mathrm{H}$ NMR $(400 \mathrm{MHz}$, Chloroform- $d$ ) $\delta 8.06(\mathrm{~d}$, $J=8.4 \mathrm{~Hz}, 1 \mathrm{H}), 7.59-7.47(\mathrm{~m}, 1 \mathrm{H}), 7.39(\mathrm{t}, J=7.9 \mathrm{~Hz}, 1 \mathrm{H}), 7.33(\mathrm{~d}, J=8.5 \mathrm{~Hz}, 1 \mathrm{H}), 7.12(\mathrm{~m}$, $1 \mathrm{H}), 6.93(\mathrm{t}, J=6.4 \mathrm{~Hz}, 1 \mathrm{H}), 6.15(\mathrm{~d}, J=5.9 \mathrm{~Hz}, 1 \mathrm{H}), 4.95(\mathrm{~s}, 1 \mathrm{H}), 4.72(\mathrm{~m}, 1 \mathrm{H}), 4.61(\mathrm{~m}, 1 \mathrm{H})$, $4.18(\mathrm{~m}, 1 \mathrm{H}), 3.44(\mathrm{t}, J=8.1 \mathrm{~Hz}, 1 \mathrm{H}), 3.27(\mathrm{~s}, 1 \mathrm{H}), 2.92(\mathrm{~d}, J=8.2 \mathrm{~Hz}, 2 \mathrm{H}), 2.74(\mathrm{~s}, 3 \mathrm{H}), 2.39(\mathrm{~s}$, $1 \mathrm{H}), 2.01(\mathrm{~m}, 2 \mathrm{H}), 1.77(\mathrm{~m}, 2 \mathrm{H}), 1.72(\mathrm{~d}, J=14.5 \mathrm{~Hz}, 2 \mathrm{H}), 1.49(\mathrm{~s}, 1 \mathrm{H}), 1.44(\mathrm{~s}, 3 \mathrm{H}), 1.23(\mathrm{~s}$, 3H), 1.22-1.20 (m, 2H), 0.75 (s, 3H). ${ }^{13} \mathrm{C}$ NMR (101 MHz, Chloroform-d) $\delta 170.2,158.3,151.9$, $150.7,141.1,136.4,136.1,129.5,128.2,125.6,125.0,123.0,122.6,117.8,80.5,74.9,71.7,64.1$, 51.6, 42.7, 38.4, 34.7, 34.2, 28.6, 28.0, 25.6, 22.5, 20.4, 19.4, 18.7. HRMS (ESI) $m / z$ 492.2748 [M $+\mathrm{H}]^{+}$, calculated for $\mathrm{C}_{30} \mathrm{H}_{38} \mathrm{NO}_{5}, 492.2744$.

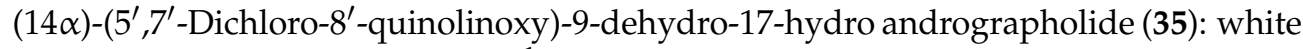
solid; m.p. 88.7-89.2 ${ }^{\circ} \mathrm{C} ; 79.2 \%$ yield; ${ }^{1} \mathrm{H}$ NMR $(400 \mathrm{MHz}$, Chloroform- $d) \delta 8.99(\mathrm{~m}, 1 \mathrm{H})$, $8.57(\mathrm{~m}, 1 \mathrm{H}), 7.69(\mathrm{~s}, 1 \mathrm{H}), 7.59(\mathrm{~m}, 1 \mathrm{H}), 6.87(\mathrm{~m}, 1 \mathrm{H}), 6.48(\mathrm{~d}, J=5.2 \mathrm{~Hz}, 1 \mathrm{H}), 4.78-4.72(\mathrm{~m}$, $1 \mathrm{H}), 4.43(\mathrm{~m}, 1 \mathrm{H}), 4.17(\mathrm{~d}, J=11.2 \mathrm{~Hz}, 1 \mathrm{H}), 3.38(\mathrm{~m}, 1 \mathrm{H}), 3.29(\mathrm{~d}, J=11.2 \mathrm{~Hz}, 1 \mathrm{H}), 2.79$ $(\mathrm{m}, 1 \mathrm{H}), 2.70-2.50(\mathrm{~m}, 2 \mathrm{H}), 2.42(\mathrm{~s}, 1 \mathrm{H}), 1.97(\mathrm{~d}, J=6.6 \mathrm{~Hz}, 1 \mathrm{H}), 1.80-1.73(\mathrm{~m}, 1 \mathrm{H}), 1.70(\mathrm{~d}$, $J=4.9 \mathrm{~Hz}, 1 \mathrm{H}), 1.54(\mathrm{~s}, 1 \mathrm{H}), 1.44(\mathrm{~s}, 3 \mathrm{H}), 1.21(\mathrm{~s}, 3 \mathrm{H}), 1.13(\mathrm{~d}, J=12.6 \mathrm{~Hz}, 1 \mathrm{H}), 1.04-0.99(\mathrm{~m}$, $1 \mathrm{H}), 0.96(\mathrm{~d}, J=6.7 \mathrm{~Hz}, 1 \mathrm{H}), 0.90-0.87(\mathrm{~m}, 1 \mathrm{H}), 0.85-0.82(\mathrm{~m}, 1 \mathrm{H}), 0.79(\mathrm{~s}, 3 \mathrm{H}) .{ }^{13} \mathrm{C}$ NMR (101 MHz, Chloroform-d) $\delta 170.3,150.9,150.6,147.5,143.4,135.6,133.8,129.4,128.0,127.9$, 127.1, 126.4, 124.7, 122.3, 80.3, 76.8, 71.7, 64.1, 51.5, 42.7, 38.4, 34.6, 34.1, 28.6, 28.0, 22.4, 20.6, 19.4, 18.7. HRMS (ESI) $m / z 546.1812[\mathrm{M}+\mathrm{H}]^{+}$, calculated for $\mathrm{C}_{29} \mathrm{H}_{34} \mathrm{NO}_{5} \mathrm{Cl}_{2}, 546.1809$.

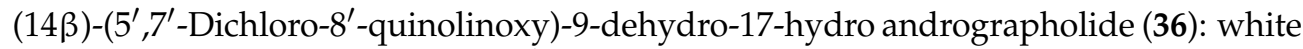
solid; m.p. $139.8-140.6^{\circ} \mathrm{C}$; $73 \%$ yield; ${ }^{1} \mathrm{H}$ NMR $(400 \mathrm{MHz}$, Chloroform- $d) \delta 8.97(\mathrm{~m}, 1 \mathrm{H})$, $8.57(\mathrm{~m}, 1 \mathrm{H}), 7.68(\mathrm{~s}, 1 \mathrm{H}), 7.58(\mathrm{~m}, 1 \mathrm{H}), 6.87-6.78(\mathrm{~m}, 1 \mathrm{H}), 6.45(\mathrm{~d}, J=5.1 \mathrm{~Hz}, 1 \mathrm{H}), 4.77$ $(\mathrm{d}, J=11.1 \mathrm{~Hz}, 1 \mathrm{H}), 4.46(\mathrm{~m}, 1 \mathrm{H}), 4.13(\mathrm{~d}, J=11.2 \mathrm{~Hz}, 1 \mathrm{H}), 3.49-3.35(\mathrm{~m}, 1 \mathrm{H}), 3.25(\mathrm{~d}$, $J=11.1 \mathrm{~Hz}, 1 \mathrm{H}), 2.80(\mathrm{~m}, 1 \mathrm{H}), 2.69(\mathrm{~s}, 1 \mathrm{H}), 2.46(\mathrm{~m}, 1 \mathrm{H}), 2.36(\mathrm{~s}, 1 \mathrm{H}), 1.96(\mathrm{~d}, J=6.5 \mathrm{~Hz}, 2 \mathrm{H})$, $1.80-1.67(\mathrm{~m}, 3 \mathrm{H}), 1.53-1.46(\mathrm{~m}, 1 \mathrm{H}), 1.40(\mathrm{~s}, 3 \mathrm{H}), 1.30(\mathrm{~s}, 1 \mathrm{H}), 1.21(\mathrm{~s}, 3 \mathrm{H}), 1.15(\mathrm{~d}, J=12.5$ $\mathrm{Hz}, 2 \mathrm{H}), 0.67$ (s, 3H). ${ }^{13} \mathrm{C}$ NMR (101 MHz, Chloroform- $d$ ) $\delta$ 170.3, 150.6, 150.1, 147.5, 143.3, $135.7,133.8,129.7,128.0,127.9,127.0,126.4,125.0,122.3,80.4,76.9,71.9,64.1,51.6,42.7,38.3$, $34.7,34.1,28.5,27.9,22.4,20.4,19.3,18.6$. HRMS (ESI) $m / z 546.1812[\mathrm{M}+\mathrm{H}]^{+}$, calculated for $\mathrm{C}_{29} \mathrm{H}_{34} \mathrm{NO}_{5} \mathrm{Cl}_{2}, 546.1809$.

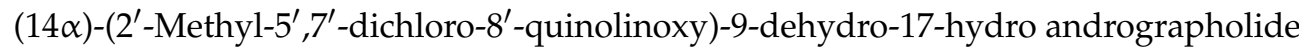
(37): white solid; m.p. $115.1-115.7^{\circ} \mathrm{C} ; 76.3 \%$ yield; ${ }^{1} \mathrm{H}$ NMR (400 MHz, DMSO-d6) $\delta 8.48$ $(\mathrm{d}, J=8.6 \mathrm{~Hz}, 1 \mathrm{H}), 7.93(\mathrm{~s}, 1 \mathrm{H}), 7.68(\mathrm{~d}, J=8.6 \mathrm{~Hz}, 1 \mathrm{H}), 6.51(\mathrm{~m}, 2 \mathrm{H}), 4.93(\mathrm{~s}, 1 \mathrm{H}), 4.63(\mathrm{~d}$, $J=11.1 \mathrm{~Hz}, 1 \mathrm{H}), 4.54(\mathrm{~m}, 1 \mathrm{H}), 4.01(\mathrm{~s}, 1 \mathrm{H}), 3.76(\mathrm{~d}, J=10.9 \mathrm{~Hz}, 1 \mathrm{H}), 3.22(\mathrm{~d}, J=11.1 \mathrm{~Hz}$, $1 \mathrm{H}), 3.10(\mathrm{t}, J=8.2 \mathrm{~Hz}, 1 \mathrm{H}), 2.75(\mathrm{~s}, 3 \mathrm{H}), 2.40(\mathrm{~m}, 1 \mathrm{H}), 1.87(\mathrm{~d}, J=6.3 \mathrm{~Hz}, 2 \mathrm{H}), 1.66-1.49(\mathrm{~m}$, $3 \mathrm{H}), 1.39(\mathrm{~s}, 3 \mathrm{H}), 1.33(\mathrm{~s}, 3 \mathrm{H}), 1.02(\mathrm{~d}, J=7.8 \mathrm{~Hz}, 3 \mathrm{H}), 0.86(\mathrm{~s}, 1 \mathrm{H}), 0.68(\mathrm{~s}, 3 \mathrm{H}) .{ }^{13} \mathrm{C}$ NMR (101 MHz, DMSO-d6) $\delta$ 169.7, 160.4, 148.7, 146.6, 142.5, 136.1, 133.4, 128.5, 127.0, 126.6, 126.2, 125.3, 124.2, 124.1, 78.1, 76.6, 71.5, 62.7, 51.2, 42.1, 38.1, 34.3, 33.9, 27.8, 27.6, 24.9, 22.9, 19.8, 19.1, 18.9. HRMS (ESI) $m / z 560.1967[\mathrm{M}+\mathrm{H}]^{+}$, calculated for $\mathrm{C}_{30} \mathrm{H}_{36} \mathrm{NO}_{5} \mathrm{Cl}_{2}, 560.1965$. 
(14ß)-(2'-Methyl-5', $7^{\prime}$-dichloro-8' -quinolinoxy)-9-dehydro-17-hydro andrographolide (38): white solid; m.p. $139.8-140.6{ }^{\circ} \mathrm{C} ; 78.6 \%$ yield; ${ }^{1} \mathrm{H}$ NMR $(400 \mathrm{MHz}$, Chloroform- $d$ ) $\delta$ $8.42(\mathrm{~d}, J=8.7 \mathrm{~Hz}, 1 \mathrm{H}), 7.60(\mathrm{~s}, 1 \mathrm{H}), 7.42(\mathrm{~d}, J=8.7 \mathrm{~Hz}, 1 \mathrm{H}), 6.81(\mathrm{~m}, 1 \mathrm{H}), 6.39(\mathrm{~d}, J=5.0 \mathrm{~Hz}$, $1 \mathrm{H}), 4.79(\mathrm{~d}, J=11.0 \mathrm{~Hz}, 1 \mathrm{H}), 4.46(\mathrm{~m}, 1 \mathrm{H}), 4.14(\mathrm{~d}, J=11.2 \mathrm{~Hz}, 1 \mathrm{H}), 3.42(\mathrm{~m}, 1 \mathrm{H}), 3.26(\mathrm{~d}$, $J=11.2 \mathrm{~Hz}, 1 \mathrm{H}), 2.86(\mathrm{~m}, 1 \mathrm{H}), 2.77(\mathrm{~s}, 3 \mathrm{H}), 2.71(\mathrm{~s}, 1 \mathrm{H}), 2.58(\mathrm{~m}, 1 \mathrm{H}), 2.34(\mathrm{~s}, 1 \mathrm{H}), 2.05-1.91$ $(\mathrm{m}, 2 \mathrm{H}), 1.74(\mathrm{~m}, 3 \mathrm{H}), 1.49(\mathrm{~m}, 1 \mathrm{H}), 1.39(\mathrm{~s}, 3 \mathrm{H}), 1.33(\mathrm{~d}, J=12.9 \mathrm{~Hz}, 1 \mathrm{H}), 1.22(\mathrm{~s}, 3 \mathrm{H})$, 1.20-1.13 (m, 2H), $0.71(\mathrm{~s}, 3 \mathrm{H}) .{ }^{13} \mathrm{C}$ NMR (101 MHz, Chloroform-d) $\delta 170.4,160.1,150.0$, 147.0, 142.9, 135.8, 133.7, 129.7, 127.7, 126.9, 126.9, 125.1 124.7, 123.2, 80.4, 72.0, 64.1, 51.6, $42.7,38.3,34.6,34.2,31.6,28.6,27.9,25.3,22.4,20.3,19.3,18.7$. HRMS (ESI) $m / z 560.1967$ [M $+\mathrm{H}]^{+}$, calculated for $\mathrm{C}_{30} \mathrm{H}_{36} \mathrm{NO}_{5} \mathrm{Cl}_{2}, 560.1965$.

\subsection{Cell Lines and Treatments}

Human HEK293 cells (ATCC, \# CRL-1573) were cultured at $37^{\circ} \mathrm{C}, 5 \% \mathrm{CO}_{2}$ in DMEM supplemented with $10 \%$ FBS, penicillin $(100 \mathrm{U} / \mathrm{mL})$, and streptomycin $(50 \mathrm{mg} / \mathrm{mL})$. Human SH-SY5Y neuroblastoma cells (gift from Dr Narisorn Kitiyanant, Mahidol University) were grown at $37^{\circ} \mathrm{C}, 5 \% \mathrm{CO}_{2}$ in high glucose-DMEM supplemented with $10 \% \mathrm{FBS}$, penicillin $(100 \mathrm{U} / \mathrm{mL})$, and streptomycin $(50 \mathrm{mg} / \mathrm{mL})$. Andrographolide was prepared as a $100 \mathrm{mM}$ stock solution (in 100\% DMSO) and derivatives were prepared as a $10 \mathrm{mM}$ stock solution (in 100\% DMSO) from which serial dilutions were prepared. Cells were treated for $24 \mathrm{~h}$ before being processed for $\mathrm{SAPP} \alpha$ secretion and Western blot analysis. For all conditions (including non-treated controls), DMSO was adjusted to $0.1 \%$.

\section{5. $s A P P \alpha$ Secretion and Detection}

Secretion and detection of SAPP $\alpha$ in HEK293 and SH-SY5Y cells with the humanspecific monoclonal anti-sAPP $\alpha$ antibody (2B3) has been previously described [58]. Briefly, following treatments in complete media, media was removed, and cells were incubated with fresh DMEM $(1 \mathrm{~mL})$ and allowed to secrete for $5 \mathrm{~h}$. Then, 10\% TCA precipitation of the whole medium was performed, and the precipitate was subjected to electrophoresis through 10\% SDS-PAGE gels, transferred onto nitrocellulose membranes (100 $\mathrm{min}$, 90 volts), incubated in $5 \%$ non-fat milk blocking solution for $30 \mathrm{~min}$ and incubated overnight at $4{ }^{\circ} \mathrm{C}$ with $2 \mathrm{~B} 3(1 \mu \mathrm{g} / \mathrm{mL}$ ). After three washes with PBST (PBS containing $0.05 \%$ Tween 20), membranes were then incubated with a HRP-conjugated anti-mouse IgG antibody (dilution 1/3000), rinsed three times with PBST incubated with ECL reagent, and signals were detected using an Azure c400 (Azure Biosystems, Dublin, CA, USA). Band densities were measured with the Image J software.

\subsection{Western Blot Analyses}

Cells were collected with phosphate-buffered saline (PBS)-EDTA and resuspended in 70 to $100 \mu \mathrm{L}$ of lysis buffer $(10 \mathrm{mM}$ Tris/ $\mathrm{HCl}, \mathrm{pH} 7.5,150 \mathrm{mM} \mathrm{NaCl}, 0.5 \%$ triton X$100,0.5 \%$ deoxycholate, $5 \mathrm{mM}$ EDTA). Protein concentrations were determined by the Bradford method [59] and 20-40 $\mu \mathrm{g}$ proteins were loaded onto 10\% of SDS-PAGE gels which were run at 100 volts for $2-2.5 \mathrm{~h}$. Proteins were then transferred onto nitrocellulose membranes for 60-120 min at 90 V). Protein transfer was verified by Ponceau red staining, and nitrocellulose membranes were subsequently incubated in 5\% non-fat milk blocking solution for $45 \mathrm{~min}$. Membranes were then incubated with primary antibodies directed against $\beta$ APP (dilution 1/2000), ADAM10 (dilution 1/500), BACE1 (dilution 1/1000), or $\beta$-actin (dilution $1 / 5000$ ) on a platform shaker overnight at $4{ }^{\circ} \mathrm{C}$. Bound antibodies were detected using goat anti-mouse (dilution 1/3000, polyclonal 7076, Cell Signaling) or goat anti-rabbit peroxidase-conjugated antibody (dilution 1/3000, polyclonal 7074, Cell Signaling). After 3 washes with PBST, membranes were incubated with a HRP-conjugated anti-rabbit (ADAM10, $\beta$ APP and BACE1) or anti-mouse ( $\beta$-actin) secondary antibody $(1 / 3000)$ for $2 \mathrm{~h}$, rinsed 3 times with PBST, and processed as described above. All protein levels were normalized using $\beta$-actin as an internal standard. 


\subsection{Cell Viability Assay}

Cells were seeded in 96-well polystyrene-coated tissue culture plates (Corning) over night. Proper attachment and confluence of the cells were confirmed by checking under a microscope. Media was removed and cells were treated with the compounds at various concentrations in quadruplicate for $24 \mathrm{~h}$ with control cells being treated with vehicle $(0.1 \%$ DMSO). Media was then removed and cells were washed with sterile milli-Q water. Then, (3-(4,5-dimethylthiazol-2-yl)-2,5-diphenyltetrazolium bromide (MTT) was added $(0.5 \mathrm{mg} / \mathrm{mL})$ for $1.5 \mathrm{~h}$. Formazan crystals formation was then checked under a microscope and the media was replaced by $100 \%$ DMSO until the purple crystals dissolved. Absorbance was measured at $595 \mathrm{~nm}$.

\subsection{Real-Time Quantitative Polymerase Chain Reaction ( $q-P C R$ )}

Following treatments without (control) or with andrographolide or andrographolide derivative for $24 \mathrm{~h}$ at $37^{\circ} \mathrm{C}$ in $1 \mathrm{~mL}$ of DMEM containing $1 \%$ FBS, total RNA was extracted from HEK293 or SH-SY5Y cells and purified with the PureLink RNA mini kit (Ambion, Life Technologies, Austin, TX, USA). Real-time PCR was performed with $100 \mathrm{ng}$ of total RNA using the QuantiFast SYBR Green RT-PCR kit (Qiagen, Singapore) detector system (Eppendorf Mastercycler ep RealPlex, Eppendorf, Hamburg, Germany) and the SYBR Green detection protocol. The 2x QuantiFast SYBR Green RT-PCR master mix, QuatiFast RT mix, QuantiTectPrimer Assay, and template RNA were mixed and the reaction volume was adjusted to $25 \mu \mathrm{L}$ using RNase-free water. The specific primers were designed and purchased from Qiagen. Each primer was added to a 10× QuantiTect Primer Assay containing a mix of forward and reverse primers for specific targets: Hs_ADAM10_1_SG (QT00032641, human ADAM10), Hs_BACE1_1_SG (QT00084777, human BACE1), and Hs_GAPDH_1_SG (QT00079247, human GAPDH, housekeeping gene for normalization).

\section{9. $\alpha$-Secretase Fluorimetric Assay on Intact Cells}

SH-SY5Y and HEK293 cells were cultured in $35 \mathrm{~mm}$-dishes coated with polylysine $(10 \mu \mathrm{g} / \mathrm{mL})$ until cells reached $80 \%$ confluence. Cells were treated in duplicate without (control) or with various concentrations of andrographolide or andrographolide derivatives for $24 \mathrm{~h}$ at $37^{\circ} \mathrm{C}$ in $1 \mathrm{~mL}$ of DMEM containing $1 \%$ FBS. Duplicates were then incubated for $30 \mathrm{~min}$ at $37^{\circ} \mathrm{C}$ in the absence or in the presence of the general metalloprotease inhibitor 0 phenanthroline $(100 \mu \mathrm{M})$ in $1.5 \mathrm{~mL}$ of PBS. Then, the $\alpha$-secretase-specific JMV2770 substrate $(10 \mu \mathrm{M})[60]$ was directly added into the media and cells were maintained at $37^{\circ} \mathrm{C}$. Every $15 \mathrm{~min}, 100 \mu \mathrm{L}$ of media were removed and the $\alpha$-secretase-specific activity corresponding to the $o$-phenanthroline-sensitive fluorescence was recorded in black 96-well plates at $320 \mathrm{~nm}$ and $420 \mathrm{~nm}$ excitation and emission wavelengths, respectively.

\subsection{0. $\beta$-Secretase Fluorimetric Assay on Cell Homogenates}

SH-SY5Y and HEK293 cells were cultured in $35 \mathrm{~mm}$-dishes until they reach $80 \%$ confluence, treated without (control) or with various concentrations of andrographolide or andrographolide derivatives for $24 \mathrm{~h}$ at $37^{\circ} \mathrm{C}$ in DMEM containing $1 \% \mathrm{FBS}$ and assayed for their $\beta$-secretase activity as previously described [61]. Briefly, cells were collected, lysed with Tris $10 \mathrm{mM} \mathrm{pH} \mathrm{7.5,} \mathrm{homogenized,} \mathrm{and} \mathrm{kept} \mathrm{on} \mathrm{ice.} \mathrm{Samples} \mathrm{were} \mathrm{assayed} \mathrm{for} \mathrm{their}$ protein contents with the Bradford method and adjusted to a $3 \mu \mathrm{g} / \mu \mathrm{L}$ concentration. Then, $30 \mu \mathrm{g}$ of each sample $(10 \mu \mathrm{L})$ diluted in $10 \mathrm{mM}$ sodium acetate buffer $\mathrm{pH} 4.5$ were incubated for $30 \mathrm{~min}$ at $37^{\circ} \mathrm{C}$ in black 96-well plates (in a final volume of $100 \mu \mathrm{L}$ ) in the absence (triplicate) or in the presence (triplicate) of the $\beta$-secretase specific inhibitor JMV1197. Then, the $\beta$-secretase-specific JMV2236 substrate $(10 \mu \mathrm{M})$ was added to all samples and plates were maintained at $37^{\circ} \mathrm{C}$. Every $15 \mathrm{~min}$, the $\beta$-secretase-specific activity corresponding to the JMV1197-sensitive fluorescence was recorded at $320 \mathrm{~nm}$ and $420 \mathrm{~nm}$ excitation and emission wavelengths, respectively. 


\subsection{Statistical Analysis}

Statistical analyses were performed with the Prism software (GraphPad, San Diego, USA) using an unpaired $t$-test for pairwise comparisons. All results are expressed as means \pm SEM and $p$ values equal to or less than 0.05 were considered significant.

Supplementary Materials: The following are available online. NMR spectra for Scheme 1; NMR spectra for Scheme 2.

Author Contributions: B.V. and G.-C.Z. conceptualized and coordinated the study. A.D. performed most of the biology parts of the study. R.C. and F.L. performed the chemistry part of the work (synthesis and NMR analyses of the compounds). S.M. contributed some of the biology parts of the study. J.-F.H. synthetized and provided the fluorimetric substrates for $\alpha$-secretase (JMV2770) and $\beta$-secretase (JMV2236) assays as well as the $\beta$-secretase inhibitor JMV1197. B.V. analyzed the data related to the biological assays. B.V. wrote the manuscript with valuable inputs from the other coauthors. Financial support was obtained by B.V. and G.-C.Z. All authors have read and agreed to the published version of the manuscript.

Funding: This work was supported by Mahidol University to B.V. (NDFR 13/2564) and The Thailand Research Fund to B.V. (BRG6180002). A.D. and S.M. were supported by a Mahidol University postdoctoral research sponsorship. The work was partially supported by the National Natural Science Foundation of China to G.-C.Z. (30973621 and U0632001).

Data Availability Statement: The data presented in this study are available in this article.

Acknowledgments: We would like to thank Narisorn Kitiyanant (Institute of Molecular Biosciences, Mahidol University, Thailand) for providing us with the SH-SY5Y cell line.

Conflicts of Interest: The authors declare no conflict of interest.

Sample Availability: Samples of the compounds are available from the authors.

\section{References}

1. Querfurth, H.W.; LaFerla, F.M. Alzheimer's disease. N. Engl. J. Med. 2010, 362, 329-344. [CrossRef] [PubMed]

2. Agostinho, P.; Pliassova, A.; Oliveira, C.R.; Cunha, R.A. Localization and trafficking of amyloid- $\beta$ protein precursor protein and secretases: Impact on Alzheimer's disease. J. Alzheimers. Dis. 2015, 45, 329-347. [CrossRef]

3. Mockett, B.G.; Richter, M.; Abraham, W.C.; Muller, U.C. Therapeutic potential of secreted amyloid precursor protein APPs $\alpha$. Front. Mol. Neurosci. 2017, 10, 30. [CrossRef]

4. Vincent, B.; Govitrapong, P. Activation of the $\alpha$-secretase processing of A $\beta P P$ as a therapeutic approach in Alzheimer's disease. J. Alzheimers Dis. 2011, 24, 75-94. [CrossRef]

5. Wang, Y.Q.; Qu, D.H.; Wang, K. Therapeutic approaches to Alzheimer's disease through stimulating of non-amyloidogenic processing of amyloid precursor protein. Eur. Rev. Med. Pharmacol. Sci. 2016, 20, 2389-2403.

6. Barao, S.; Moechars, D.; Lichtenthaler, S.F.; De Strooper, B. BACE1 physiological functions may limit its use as therapeutic target for Alzheimer's disease. Trends Neurosci. 2016, 39, 158-169. [CrossRef]

7. Xia, W. $\gamma$-secretase and its modulators: Twenty years and beyond. Neurosci. Lett. 2019, 701, 162-169. [CrossRef]

8. Vincent, B.; Checler, F. $\alpha$-secretase in Alzheimer's disease and beyond: Mechanistic, regulation and function in the shedding of membrane proteins. Curr. Alzheimer Res. 2012, 9, 140-156. [CrossRef] [PubMed]

9. Wollen, K.A. Alzheimer's disease: The pros and cons of pharmaceuticals, nutritional, botanical, and stimulatory therapies, with a discussion of treatment strategies from the perspective of patients and practitioners. Altern. Med. Rev. 2010, 15, 223-244.

10. Dai, Y.; Chen, S.R.; Chai, L.; Zhao, J.; Wang, Y.; Wang, Y. Overview of pharmacological activities of Andrographis paniculata and its major compound andrographolide. Crit. Rev. Food Sci. Nutr. 2019, 59, S17-S29. [CrossRef] [PubMed]

11. Varella-Nallar, L.; Arredondo, S.B.; Tapia-Rojas, C.; Hancke, J.; Inestrosa, N.C. Andrographolide stimulates neurogenesis in the adult hippocampus. Neural Plast. 2015, 2015, 935403. [CrossRef] [PubMed]

12. Xu, Y.; Wei, H.; Wang, J.; Wang, W.; Gao, J. Synthesis of andrographolide analogues and their neuroprotection and neurite outgrowth-promoting activities. Bioorg. Med. Chem. 2019, 27, 2209-2219. [CrossRef] [PubMed]

13. Seo, J.Y.; Pyo, E.; An, J.P.; Kim, J.; Sung, S.H.; Oh, W.K. Andrographolide activates Keap1/Nrf2/ARE/HO-1 pathway in HT22 cells and suppresses microglial activation by $\mathrm{A} \beta_{42}$ through Nrf2-related inflammatory response. Mediat. Inflamm. 2017, 2017, 5906189. [CrossRef] [PubMed]

14. Yang, R.; Liu, S.; Zhou, J.; Bu, S.; Zhang, J. Andrographolide attenuates microglia-mediated A $\beta$ neurotoxicity partially through inhibiting NF-KB and JNK MAPK signaling pathway. Immunopharmacol. Immunotoxicol. 2017, 39, 276-284. [CrossRef] [PubMed]

15. Gu, L.; Yu, Q.; Li, Q.; Zhang, L.; Lu, H.; Zhang, X. Andrographolide protects PC12 cells against $\beta$-amyloid-induced autophagyassociated cell death through activation of the Nrf2-mediated p62 signaling pathway. Int. J. Mol. Sci. 2018, 19, 2844. [CrossRef] 
16. Serrano, F.G.; Tapia-Rojas, C.; Carvajal, F.J.; Hancke, J.; Cerpa, W.; Inestrosa, N.C. Andrographolide reduces cognitive impairment in young and mature A $\beta$ PPswe/PS-1 mice. Mol. Neurodegener. 2014, 9, 61. [CrossRef]

17. Geng, J.; Liu, W.; Xiong, Y.; Ding, H.; Jiang, C.; Yang, X.; Li, X.; Elgehama, A.; Sun, Y.; Xu, Q.; et al. Andrographolide sulfonate improves Alzheimer-associated phenotypes and mitochondrial dysfunction in APP/PS1 transgenic mice. Biomed. Pharmacother. 2018, 97, 1032-1039. [CrossRef]

18. Cisternas, P.; Oliva, C.A.; Torres, V.I.; Barrera, D.P.; Inestrosa, N.C. Presynptomatic treatment with andrographolide improves brain metabolic markers and cognitive behavior in a model of early-onset Alzheimer's disease. Front. Cell. Neurosci. 2019, 13, 295. [CrossRef]

19. Rivera, D.S.; Lindsay, C.; Codocedo, J.F.; Morel, I.; Pinto, C.; Cisternas, P.; Bozinovic, F.; Inestrosa, N.C. Andrographolide recovers cognitive impairment in a natural model of Alzheimer's disease (Octodon degus). Neurobiol. Aging 2016, 46, 204-220. [CrossRef]

20. Lindsay, C.B.; Zolezzi, J.M.; Rivera, D.S.; Cisternas, P.; Bozinovic, F.; Inestrosa, N.C. Andrographolide reduces neuroinflammation and oxidative stress in aged Octodon degus. Mol. Neurobiol. 2020, 57, 1131-1145. [CrossRef]

21. Tapia-Rojas, C.; Schuller, A.; Lindsay, C.B.; Ureta, R.C.; Mejias-Reyes, C.; Hancke, J.; Melo, F.; Inestrosa, N.C. Andrographolide activates the canonical Wnt signaling pathway by a mechanism that implicates the non-ATP competitive inhibition of GSK-3 $\beta$ : Autoregulation of GSK-3 $\beta$ in vivo. Biochem. J. 2015, 466, 415-430. [CrossRef]

22. Inestrosa, N.C.; Tapia-Rojas, C.; Lindsay, C.B.; Zolezzi, J.M. Wnt signaling pathway dysregulation in the aging brain: Lessons from the Octodon degus. Front Cell Dev. Biol. 2020, 8, 734. [CrossRef] [PubMed]

23. Cisternas, P.; Zolezzi, J.M.; Martinez, M.; Torres, V.I.; Gong, G.W.; Inestrosa, N.C. Wnt-induced activation of glucose metabolism mediates the in vivo neuroprotective roles of Wnt signaling in Alzheimer disease. J. Neurochem. 2019, 149, 54-72. [CrossRef]

24. Inestrosa, N.C.; Varela-Nallar, L. Wnt signaling in the nervous system and in Alzheimer's disease. J. Mol. Cell Biol. 2014, 6, 64-74. [CrossRef]

25. Parr, C.; Mirzaei, N.; Christian, M.; Sastre, M. Activation of the Wnt/ $\beta$-catenin pathway represses the transcription of the $\beta$-amyloid precursor protein cleaving enzyme (BACE1) via binding of T-cell factor-4 to BACE1 promoter. FASEB J. 2015, 29, 623-635. [CrossRef] [PubMed]

26. Tapia-Rojas, C.; Burgos, P.V.; Inestrosa, N.C. Inhibition of Wnt signaling induces amyloidogenic processing of amyloid precursor protein and the production and aggregation of Amyloid- $\beta$ (A $\beta)_{42}$ peptides. J. Neurochem. 2016, 139, 1175-1191. [CrossRef]

27. Kandanur, S.G.S.; Tamang, N.; Golakoti, N.R.; Nanduri, S. Andrographolide: A natural product template for the generation of structurally and biologically diverse diterpenes. Eur. J. Med. Chem. 2019, 176, 513-533. [CrossRef]

28. Campora, M.; Francesconi, V.; Schenone, S.; Tasso, B.; Tonelli, M. Journey on naphtoquinone and anthraquinone derivatives: New insights in Alzheimer's disease. Pharmaceuticals 2021, 14, 33. [CrossRef] [PubMed]

29. Lu, J.; Ma, Y.; Wu, J.; Huang, H.; Wang, X.; Chen, Z.; Chen, J.; He, H.; Huang, C. A review for the neuroprotective effects of andrographolide in the central nervous system. Biomed. Pharmacother. 2019, 117, 109078. [CrossRef] [PubMed]

30. Prati, F.; Bergamini, C.; Fato, R.; Soukup, O.; Korabecny, J.; Andrisano, V.; Bartolini, M.; Bolognesi, M.L. Novel 8-hydroxyquinoline derivatives as multitarget compounds for the treatment of Alzheimer's disease. ChemMedChem 2016, 11, 1284-1295. [CrossRef]

31. Xia, C.L.; Wang, N.; Guo, Q.L.; Liu, Z.Q.; Wu, J.Q.; Huang, S.L.; Ou, T.M.; Tan, J.H.; Wang, H.G.; Li, D.; et al. Design, synthesis and evaluation of 2-arylethenyl-N-methylquinolinium derivatives as effective multifunctional agents for Alzheimer's disease treatment. Eur. J. Med. Chem. 2017, 130, 139-153. [CrossRef] [PubMed]

32. Li, F.; Lee, E.M.; Sun, X.; Wang, D.; Tang, H.; Zhou, G.C. Design, synthesis and discovery of andrographolide derivatives against Zika virus infection. Eur. J. Med. Chem. 2020, 187, 111925. [CrossRef]

33. Li, F.; Khanom, W.; Sun, X.; Paemanee, A.; Roytrakul, S.; Wang, D.; Smith, D.R.; Zhou, G.C. Andrographolide and its 14-aryloxy analogues inhibit Zika and Dengue virus infection. Molecules 2020, 25, 5037. [CrossRef]

34. Liu, Z.; Law, W.K.; Wang, D.; Nie, X.; Sheng, D.; Song, G.; Guo, K.; Wei, P.; Ouyang, P.; Wong, C.W.; et al. Synthesis and discovery of andrographolide derivatives as non-steroidal farnesoid X receptor (FXR) antagonists. RSC Adv. 2014, 4, 13533-13545. [CrossRef]

35. Reynolds, D.S. A short perspective on the long road to effective treatments for Alzheimer's disease. Br. J. Pharmacol. 2019, 176, 3636-3648. [CrossRef]

36. Latif, R.; Wang, C.Y. Andrographolide as a potent and promising antiviral agent. Chin. J. Nat. Med. 2020, 18, 760-769. [CrossRef]

37. Zhang, L.; Bao, M.; Liu, B.; Zhao, H.; Zhang, Y.; Ji, X.Y.; Zhao, N.; Zhang, C.; He, X.; Yi, J.; et al. Effect of andrographolide and its analogs on bacterial infection: A review. Pharmacology 2020, 105, 123-134. [CrossRef] [PubMed]

38. Farooqi, A.A.; Attar, R.; Sabitaliyevich, U.Y.; Alaaeddine, N.; de Sousa, D.P.; Xu, B.; Cho, W.C. The prowess of andrographolide as a natural weapon in the war against cancer. Cancers 2020, 12, 2159. [CrossRef]

39. Islam, M.T. Andrographolid, a new hope in the prevention and treatment of metabolic syndrome. Front. Pharmacol. 2017, 8, 571. [CrossRef] [PubMed]

40. Tan, W.S.D.; Liao, W.; Zhou, S.; Wong, W.S.F. Is there a future for andrographolide to be an anti-inflammatory drug? Deciphering its major mechanisms of action. Biochem. Pharmacol. 2017, 139, 71-81. [CrossRef] [PubMed]

41. Kishore, V.; Yarla, N.S.; Bishayee, A.; Putta, S.; Malla, R.; Neepalu, N.R.; Challa, S.; Das, S.; Shiralgi, Y.; Hedge, G.; et al. Multi-targeting andrographolide and its natural analogs as potential therapeutic agents. Curr. Top. Med. Chem. 2017, 17, 845-857. [CrossRef] 
42. Yen, T.L.; Chen, R.J.; Jayakumar, T.; Lu, W.J.; Hsieh, C.Y.; Hsu, M.J.; Yang, C.H.; Chang, C.C.; Lin, Y.K.; Lin, K.H.; et al. Andrographolide stimulates p38 mitogene-activated protein kinase-nuclear factor erythroid-2-related factor 2-heme oxygenase 1 signaling in primary cerebral endothelial cells for definite protection against ischemic stroke in rats. Transl. Res. 2016, 170, 57-72. [CrossRef]

43. Iruretagoyena, M.; Tobar, J.A.; Gonzalez, P.A.; Sepulveda, S.E.; Figueroa, C.A.; Burgos, R.A.; Hancke, J.L.; Kalergis, A.M. Andrographolide interferes with $\mathrm{T}$ cell activation and reduces experimental autoimmune encephalomyelitis in the mouse. $J$. Pharmacol. Exp. Ther. 2005, 312, 366-372. [CrossRef] [PubMed]

44. Zhang, Z.; Lai, D.; Wang, L.; Yu, P.; Zhu, L.; Guo, B.; Xu, L.; Zhou, L.; Sun, Y.; Lee, S.M.Y.; et al. Neuroprotective effects of the andrographolide analogue AL-1 in the MPP+/MPTP-indiced Parkinson's ndisease model in vitro and in mice. Pharmacol. Biochem. Behav. 2014, 122, 191-202. [CrossRef]

45. Mussard, E.; Cesaro, A.; Lespessailles, E.; Legrain, B.; Berteina-Raboin, S.; Toumi, H. Andrographolide, a natural antioxidant: An update. Antioxidants 2019, 8, 571. [CrossRef]

46. Xia, Y.F.; Ye, B.Q.; Li, Y.D.; Wang, J.G.; He, X.J.; Lin, X.; Yao, X.; Ma, D.; Slungaard, A.; Hebbel, R.P.; et al. Andrographolide attenuates inflammation by inhibition of NF-kappa B activation through covalent modification of reduced cysteine 52 of p50. J. Immunol. 2004, 173, 4207-4217. [CrossRef] [PubMed]

47. Postina, R.; Schroeder, A.; Dewachter, I.; Bohl, J.; Schmitt, U.; Kojro, E.; Prinzen, C.; Endres, K.; Hiemke, C.; Blessing, M.; et al. A disintegrin-metalloproteinase prevents amyloid plaque formation and hippocampal defects in an Alzheimer disease mouse model. J. Clin. Investig. 2004, 113, 1456-1464. [CrossRef]

48. Halima, S.B.; Mishra, S.; Raja, K.M.P.; Willem, M.; Baici, A.; Simons, K.; Brustle, O.; Koch, P.; Haass, C.; Caflisch, A.; et al. Specific inhibition of $\beta$-secretase processing of the Alzheimer disease amyloid precursor protein. Cell Rep. 2016, 14, 2127-2141. [CrossRef] [PubMed]

49. Al Batran, R.; Al-Bayaty, F.; Jamil Al-Obaidi, M.M.; Abdulla, M.A. Acute toxicity and the effect of andrographolide on Porphyromonas gingivalis-induced hyperlipidemia in rats. Biomed. Res. Int. 2013, 2013, 594012. [CrossRef] [PubMed]

50. Prakash, E.L.S.; Manavalan, R. Acute toxicity studies of andrographolide. Res. J. Pharm. Biol. Chem. Sci. $2011,2,547$.

51. Bera, R.; Ahmed, S.K.M.; Sarkar, L.; Sen, T.; Karmakar, S. Pharmacokinetic analysis and tissue distribution of andrographolide in rat by a validated LC-MS/MS method. Pharm. Biol. 2014, 52, 321-329. [CrossRef]

52. Kumar, G.; Singh, D.; Tali, J.A.; Dheer, D.; Shankar, R. Andrographolide: Chemical modification and its effect on biological activities. Bioorg. Chem. 2020, 95, 103511. [CrossRef]

53. Ren, X.; Xu, W.; Sun, J.; Dong, B.; Awala, H.; Wang, L. Current trends on repurposing and pharmacological enhancement of andrographolide. Curr. Med. Chem. 2021, 28, 2346-2368. [CrossRef]

54. Li, F.; Li, X.M.; Sheng, D.; Chen, S.R.; Nie, X.; Liu, Z.; Wang, D.; Zhao, Q.; Wang, Y.; Wang, Y.; et al. Discovery and preliminary SAR of 14-aryloxy-andrographolide derivatives as antibacterial agents with immunosuppressant activity. RSC Adv. 2018, 8, 9440-9456. [CrossRef]

55. Lu, J.; Gu, L.; Li, Q.; Wu, N.; Li, H.; Zhang, X. Andrographolide ameliorates maltol aluminium-induced neurotoxicity via regulating p62-mediated Keap1-Nrf2 pathways in PC12 cells. Pharm. Biol. 2021, 59, 232-241. [CrossRef] [PubMed]

56. Gong, C.; Xu, C.; Ji, L.; Wang, Z. A novel semi-synthetic andrographolide analogue A5 inhibits tumor angiogenesis via blocking the VEGFR2-p38/ERK1/2 signal pathway. Biosci. Trends 2013, 7, 230-236. [CrossRef] [PubMed]

57. Xiao, X.W.; Fu, H.Z.; Luo, Y.H.; Wei, X.Y. Potential anti-angiogenic sulfates of andrographolide. J. Asian Nat. Prod. Res. 2013, 15, 809-818. [CrossRef] [PubMed]

58. Shukla, M.; Htoo, H.H.; Wintachai, P.; Hernandez, J.F.; Dubois, C.; Postina, R.; Xu, H.; Checler, F.; Smith, D.R.; Govitrapong, P.; et al. Melatonin stimulates the nonamyloidogenic processing of $\beta$ APP through the positive transcriptional activation of ADAM10 and ADAM17. J. Pineal Res. 2015, 58, 151-165. [CrossRef]

59. Bradford, M.M. A rapid and sensitive method for the quantification of microgram quantities of protein utilizing the principle of protein-dye binding. Anal. Biochem. 1976, 72, 248-254. [CrossRef]

60. Cisse, M.A.; Gandreuil, C.; Hernandez, J.F.; Martinez, J.; Checler, F.; Vincent, B. Design and characterization of a novel cellular prion-derived quenched fluorimetric substrate of $\alpha$-secretase. Biochem. Biophys. Res. Commun. 2006, 347, 254-260. [CrossRef] [PubMed]

61. Andrau, D.; Dumanchin-Njock, C.; Ayral, E.; Vizzavona, J.; Farzan, M.; Boisbrun, M.; Fulcrand, P.; Hernandez, J.F.; Martinez, J.; Lefranc-Jullien, S.; et al. BACE1- and BACE2-expressing human cells. Characterization of $\beta$-amyloid precursor protein-derived catabolites, design of a novel fluorimetric assay, and identification of new in vitro inhibitors. J. Biol. Chem. 2003, 278, 25859-25866. [CrossRef] [PubMed] 